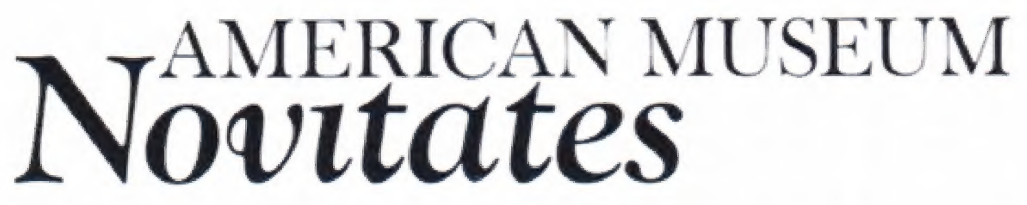

PUBLISHED BY THE AMERICAN MUSEUM OF NATURAL HISTORY
CENTRAL PARK WEST AT 79TH STREET, NEW YORK, NY 10024
Number 3324,27 pp., 12 figures

\title{
A Review of the Problematic Extinct Teleost Fish Araripichthys, with a Description of a New Species from the Lower Cretaceous of Venezuela
}

\author{
JOHN G. MAISEY ${ }^{1}$ AND JOHN M. MOODY ${ }^{2}$
}

\begin{abstract}
A new species of teleost, Araripichthys axelrodi, is described from the Lower Cretaceous (Aptian) Machiques Member of the Apon Formation, Venezuela. Its phylogenetic and biogeographic relationships are discussed; the new species represents both the oldest and the most primitive member of the genus. Araripichthys probably originated in the Pacific or western (Caribbean) Tethys and apparently dispersed eastward by the Albian, a pattern paralleled by Aptian and Albian foraminifers.

The phylogenetic position of Araripichthys is problematic; previously it has been classified either as an advanced teleost (within acanthomorphs) or at a much more primitive level within teleosts (as an elopocephalan incertae sedis). This uncertainty is compounded further by similarity to Ferrifrons and Acanthichthys (family Ferrifronsidae), two late Cretaceous genera that have been classified as primitive acanthopterygians. Araripichthys and the Ferrifronsidae display a curious mix of characters; they share some features with higher teleosts (clupeocephalans, neoteleosts, acanthomorphs), but lack (or are unknown in) many other characters of those groups. Consequently, these extinct taxa cannot be placed satisfactorily within a current phylogenetic framework of teleost fishes, but few characters support inclusion of Araripichthys within any group of higher teleosts.
\end{abstract}

\footnotetext{
${ }^{1}$ Herbert R. and Evelyn Axelrod Research Chair, Division of Paleontology, American Museum of Natural History.

${ }^{2}$ Museo de Biologia, Universidad del Zulia, Facultad Experimental de Ciencias, Edif, A1, Grano de Oro, Z.P. 4011, Ap. 526, Maracaibo, Venezuela.
} 


\section{INTRODUCTION}

Recent discoveries of mid-Cretaceous fossil fish assemblages in Venezuela (Moody and Maisey, 1993) and Colombia (Schultze and Stöhr, 1996) are of biogeographic interest because they document part of a marine ichthyofauna from the southern part of $\mathrm{Ca}$ ribbean Tethys, a region for which data were previously lacking. Until very recently, almost no fossil fish of that age were known from the western (Caribbean) part of Tethys, apart from a single fossil from Colombia now identified as Rhacolepis, a common taxon in some Albian strata from Brazil (Weeks, 1953, 1957; Silva Santos and Oliveira, 1994).

Although many fishes of the Venezuelan and Colombian assemblages are still undescribed, they all seem closely related to taxa from Brazilian near-shore and epicontinental marine and transitional deposits of Aptian and Albian age (Maisey, 2000). For example, the aspidorhynchid teleost Vinctifer occurs in Venezuela, Colombia, Brazil, Mexico, Australia, and perhaps West Africa and Antarctica (Moody and Maisey, 1993; Schultze and Stöhr, 1996). Other taxa common to Venezuela, Colombia, and Brazil include Rhacolepis and Notelops, which may also be present in the largely undescribed Tepexi assemblage from Mexico (probably of Albian age; Maisey, 2000).

The skeletal morphology of Araripichthys was first described by Silva Santos (1983, 1985a), based on several mechanically prepared specimens from the Santana Formation of Brazil. Additional acid-prepared material was described by Maisey and Blum (1991). Araripichthys is a comparatively rare taxon in the Santana Formation of Brazil, and it has not yet been recorded from any other Brazilian Cretaceous locality, so its discovery in Venezuela was unexpected. However, a single specimen of yet another species of $A r$ aripichthys was recently described by Cavin (1997a, 1997b) from the Upper Cretaceous (Lower Turonian) of Goulmima, Morocco. Thus, Araripichthys provides an excellent example of how discovery of single fossils can radically modify our notions of an extinct taxon's original distribution. In this case, two widely separated discoveries have transformed the apparently restricted occurrence of a rare and specialized taxon from Brazil into an impressive pattern spanning much of southern Tethys during the Cretaceous period (fig. 1). During the Aptian and Albian, Araripichthys was a resident of Caribbean Tethys and adjacent waters, and it survived into the Lower Turonian along the southern margin of Tethys farther to the east.

\section{MATERIALS AND METHODS}

Araripichthys is represented in Brazil, Morocco, and Venezuela by complete individuals, rather than by isolated bones or fragmentary skeletons. The Brazilian material (representing the type species) is by far the best preserved and most abundant, although it is an uncommon species in comparison with many other fossil fishes from the Santana Formation. Several specimens in the AMNH collection have been prepared in acid (Maisey and Blum, 1991). Fortunately, the Venezuelan and Moroccan specimens are both sufficiently complete to allow anatomical comparison with the type species. Several skeletal features (described below) suggest that the Venezuelan and Moroccan forms not only differ from the type species but also from each other; thus, three species are probably represented. The Venezuelan form is formally named as a new species in this work. Modified diagnoses for the family/ genus and type species are also presented, because Araripichthys is no longer monotypic.

\section{Abbreviations}

ac articular condyle of maxilla

art.s articular surface of exoccipital (forming part of occipital condyle)

Boc basioccipital

$\mathrm{C}_{1}-\mathrm{C}_{6}$ anteriormost vertebral centra (sequentially numbered)

Epi epineural

Epo epioccipital

Exo exoccipital

$\mathrm{fm}$ foramen magnum

Fr frontal

Ic intercalar

n.sp neural spine

$\mathrm{Pa}$ parietal

pmp premaxillary ascending process

pre prezygapophysis of neural arch 


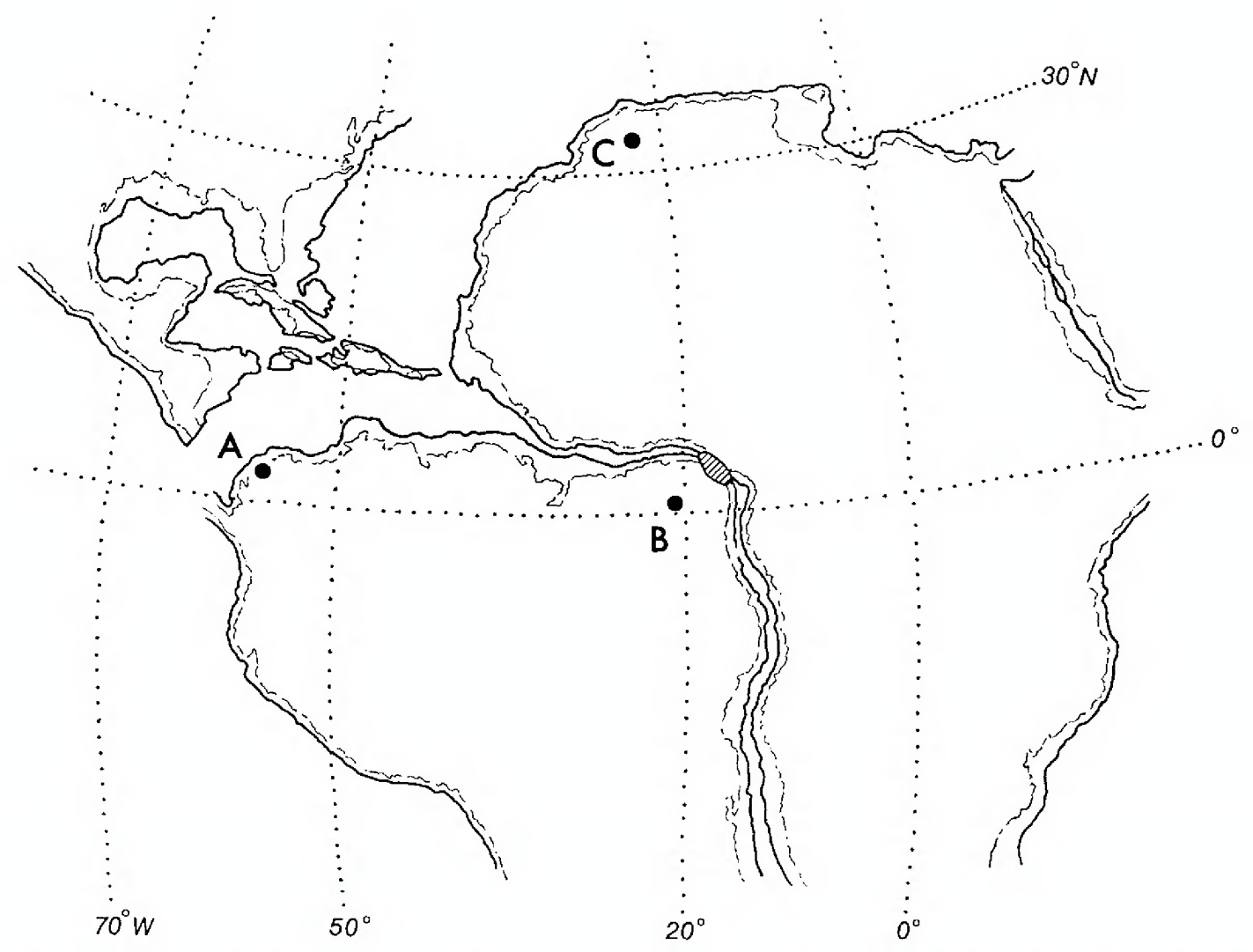

Fig. 1. Occurrences of Araripichthys discussed in the text. (A) A. axelrodi, from Venezuela (Aptian); (B) A. castilhoi, from Brazil (Albian); (C) A. corythophorus, from Morocco (Turonian).

Pro prootic

Psp parasphenoid

Pto pterotic

Ptsp pterosphenoid

Soc supraoccipital

Spo sphenotic

\section{SYSTEMATIC DESCRIPTION}

SUBDIVISION TELEOSTEI

\section{SUPERCOHORT ELOPOCEPHALA? INCERTAE SEDIS}

FAMILY ARARIPICHTHYIDAE SILVA SANTOS

Diagnosis (emended): Deep-bodied elopocephalans reaching $25-30 \mathrm{~cm}$ standard length, lacking pelvic girdle and fins; dorsal and anal fins extending to caudal peduncle, highest part of dorsal fin located above insertion of anal fin, caudal peduncle narrow; head short and high, with prominent supraoccipital crest and lateral crests dividing deep subepiotic fossa into upper and lower parts; large round opening present between pterosphenoid and sphenotic, uniting orbit with dilatator fossa; supraorbitals absent; maxilla and dentary edentulous or nearly so; vomer edentulous; premaxilla with prominent ascending process anterodorsally; two supramaxillae extending above maxilla for most of its length; abdominal region of vertebral column strongly arched; neural and hemal arches fused to respective centra; ossified epineurals with expanded, branched proximal ends, associated with anterior vertebrae; anal pterygiophore forms large, posteriorly curved plate, ridged and expanded distally (probably a compound fusion of several pterygiophores); entire body, fins, and posterior part of head covered by numerous, circular, deeply overlapping cycloid scales.

Genus Araripichthys Silva Santos Araripichthys Silva Santos, 1983: 27 (nomen nudum). 
Araripichthys Silva Santos, 1985a: 135.

Araripichthys Silva Santos; Maisey and Blum, 1991: 208.

Type SPecies: Araripichthys castilhoi Silva Santos.

DIAGNOSIS: As for family.

\section{Araripichthys castilhoi Silva Santos}

Araripichthys castilhoi Silva Santos, 1983: 27 (nomen nudum).

Araripichthys castilhoi Silva Santos, 1985a: 135.

DiAgNosis (emended): Araripichthys with elongate premaxillary ascending process accounting for almost half of premaxillary length; strongly developed articular condyle on rodlike anterior part of maxilla, with deep corresponding cotylus on vomer; supramaxillae expanded vertically and of approximately equal size; parietal posterior margin deeply embayed; epioccipital forms distinct posterior process behind parietal.

Holotype: No. 21-P33, Departamento de Biologia Animal e Vegetal, Instituto de Biologia, State University of Rio de Janeiro (UERJ), Brazil. Almost complete individual; mid-Cretaceous (Albian), Santana Formation, Chapada do Araripe, NE Brazil. Figured in Silva Santos, 1985a: pl. II: 2, 2a, 3.

\section{Araripichthys corythophorus Cavin, 1997a}

Araripichthys new species, Cavin, 1997a: 34.

Araripichthys corythophorus Cavin, 1997b: 720.

DiAGNOSIS: Araripichthys with ascending process of premaxilla slightly less than half premaxillary length (?); vomer with well-developed articular condyle for maxilla; at least one large supramaxilla present; small epioccipital and relatively straight parietal and pterotic posterior margins.

Holotype: Musée d'Histoire Naturelle de Boulogne-sur-Mer, BHN 2 P 35; Upper Cretaceous (Lower Turonian), Goulmima, Morocco. Incomplete individual lacking tail, preserved length approx. $21 \mathrm{~cm}$. Figured in Cavin, 1997a: figs. 1.9-1.11; Cavin, 1997b: fig. 2 .

\section{Araripichthys axelrodi, new species}

DiAGNOSIS: Araripichthys with dorsally directed premaxillary ascending process representing less than one-third total length of premaxilla: maxilla lacks rodlike anterior region, with weak articular surface anteriorly; supramaxillae not expanded vertically, anterior one shorter than the posterior; parietal posterior margin slightly embayed; epioccipital not forming distinct process.

Holotype: P-907 MBLUZ, University of Zulia, Paleontology Section Collection, Maracaibo, Venezuela (figs. 2, 3). Individual lacking tail, preserved length approx. $23 \mathrm{~cm}$, Machiques Member (Aptian), Apon Formation, Rosarito Quarry, near Villa del Rosario, Venezuela, collected by J. M. Moody.

Derivation of NAME: After Herbert Axelrod, in recognition of his generous support of research in paleoichthyology at the American Museum of Natural History.

STRATIGRAPHIC NotE: The holotype of Araripichthys axelrodi came from a narrow bed in the Machiques Member of the Apon Formation that produces many Deshayesites ammonites, supporting its Aptian age. The Machiques Member is considered to be Aptian, even possibly lower Aptian, but the Apon Formation spans the Aptian-Albian, and some authors speculate that its base may even be of Barremian age (discussed in Renz, 1982).

\section{MORPHOLOGICAL VARIATION IN ARARIPICHTHYS}

Araripichthys is a specialized teleost whose most evident external morphological features include a deep and laterally compressed body lacking pelvic fins (e.g., A. $a x$ elrodi, fig. 2 ; A. castilhoi, fig. 4). The genus is also characterized by elaborate and presumably highly protrusible mouthparts that closely resemble those of many acanthomorph teleosts (see figs. 3, 5, 6). As the genus is no longer monotypic, some comments are included below regarding the extent of morphological variation encompassed by the genus and reflected in the species-level diagnoses presented above. A revised familylevel diagnosis is presented above. Since the family presently contains a single genus, diagnoses are provisionally regarded as coextensive.

Many features described in the type species of Araripichthys are also present in the other two nominal species and are retained 


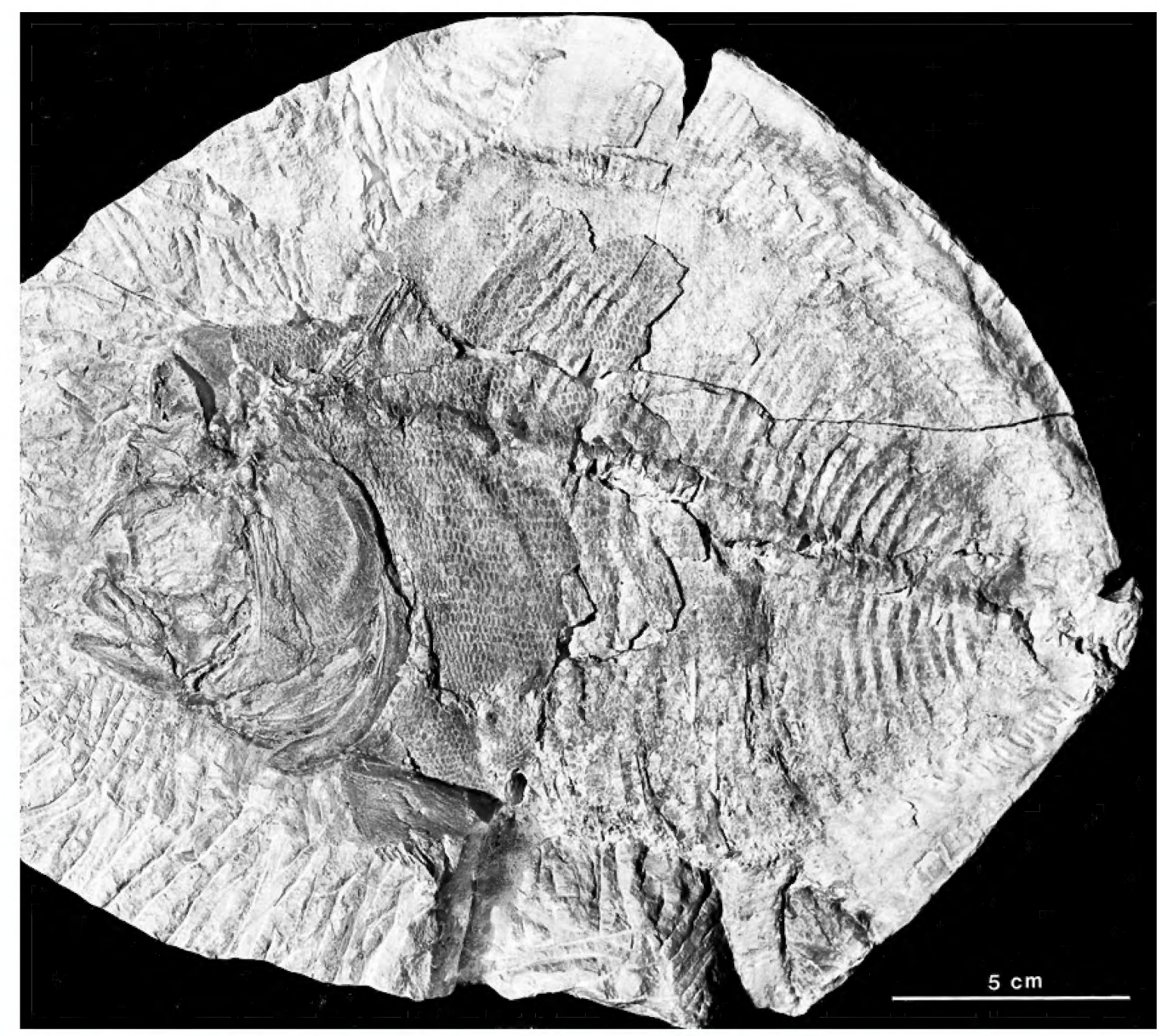

Fig. 2. Araripichthys axelrodi; the holotype, P-907 MBLUZ (entire specimen).

in the present family/genus diagnosis. Two characters previously considered diagnostic of the genus are known only in A. castilhoi and $A$. corythophorus, but have not yet been observed in $A$. axelrodi; that is, presence of an edentulous vomer, and an opening between the pterosphenoid and sphenotic connecting the orbit and dilatator fossa. These characters are provisionally retained here as diagnostic for the family Araripichthyidae. Another character previously regarded as diagnostic is the extent of the median (dorsal, anal) fins rostrocaudally. The character is present in $A$. castilhoi and A. axelrodi but it cannot be determined in the available material of $A$. corythophorus, although its median fins were evidently extremely long in the rostrocaudal axis and may well have been as extensive as in the other species (Cavin, 1997a, 1997b). This character has also been retained in the family/genus diagnosis given above.

Some other features (including several listed in the diagnosis of Araripichthys presented by Maisey and Blum, 1991: 208) are unknown in both $A$. corythophorus and A. axelrodi. Such characters may be diagnostic of the genus, only the type species, or a combination of the type and one other species. In view of this uncertainty these characters were omitted from the diagnoses presented above, as well as from the phylogenetic analysis 


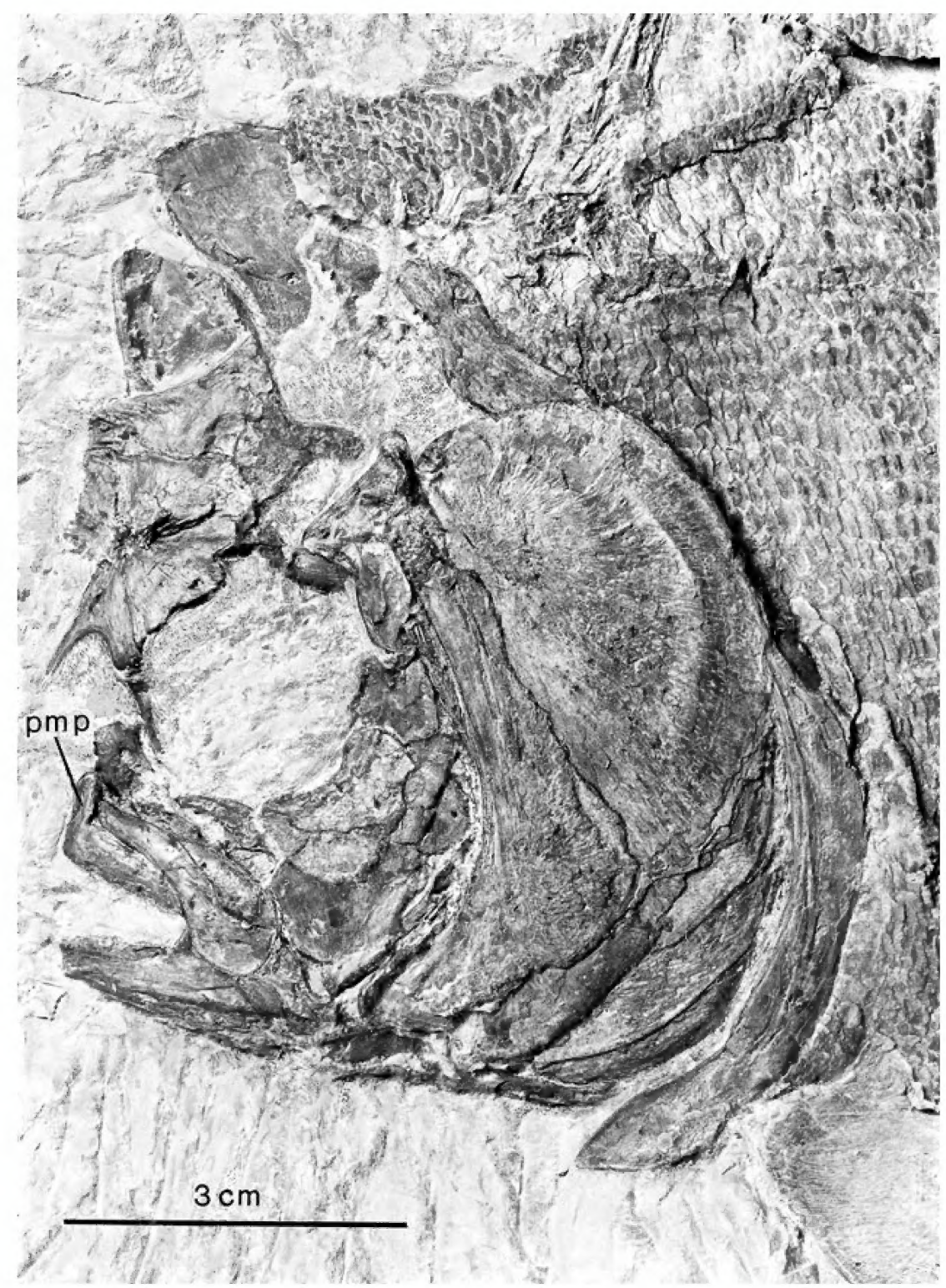

Fig. 3. Araripichthys axelrodii; the holotype, P-907 MBLUZ (detail of head). Note presence of short premaxillary process (pmp) but absence of articular condyle of maxilla.

outlined below. Characters falling into this category include:

(i) Fusion of vertebral arches and centra. In $A$. castilhoi all the neural and haemal arches and parapophyses of pleural ribs are fused to their respective centra (including those of preurals 1 and 2). Not all the centra are visible in specimens of $A$. corythophorus and $A$. axelrodi, and it is uncertain whether all three species agree in this respect. A. castilhoi is also the only species in which epineural bones have been observed (see below).

(ii) Tripartite occipital joint. See phylogenetic discussion below.

(iii) Shape of the caudal fin. This is deeply forked, but with rounded fin lobes in A. castilhoi. The caudal fin is still unknown in $A$. corythophorus and $A$. axelrodi.

(iv) Meristic data for A. castilhoi (about 86 scales along lateral line, 33 scales in ver- 


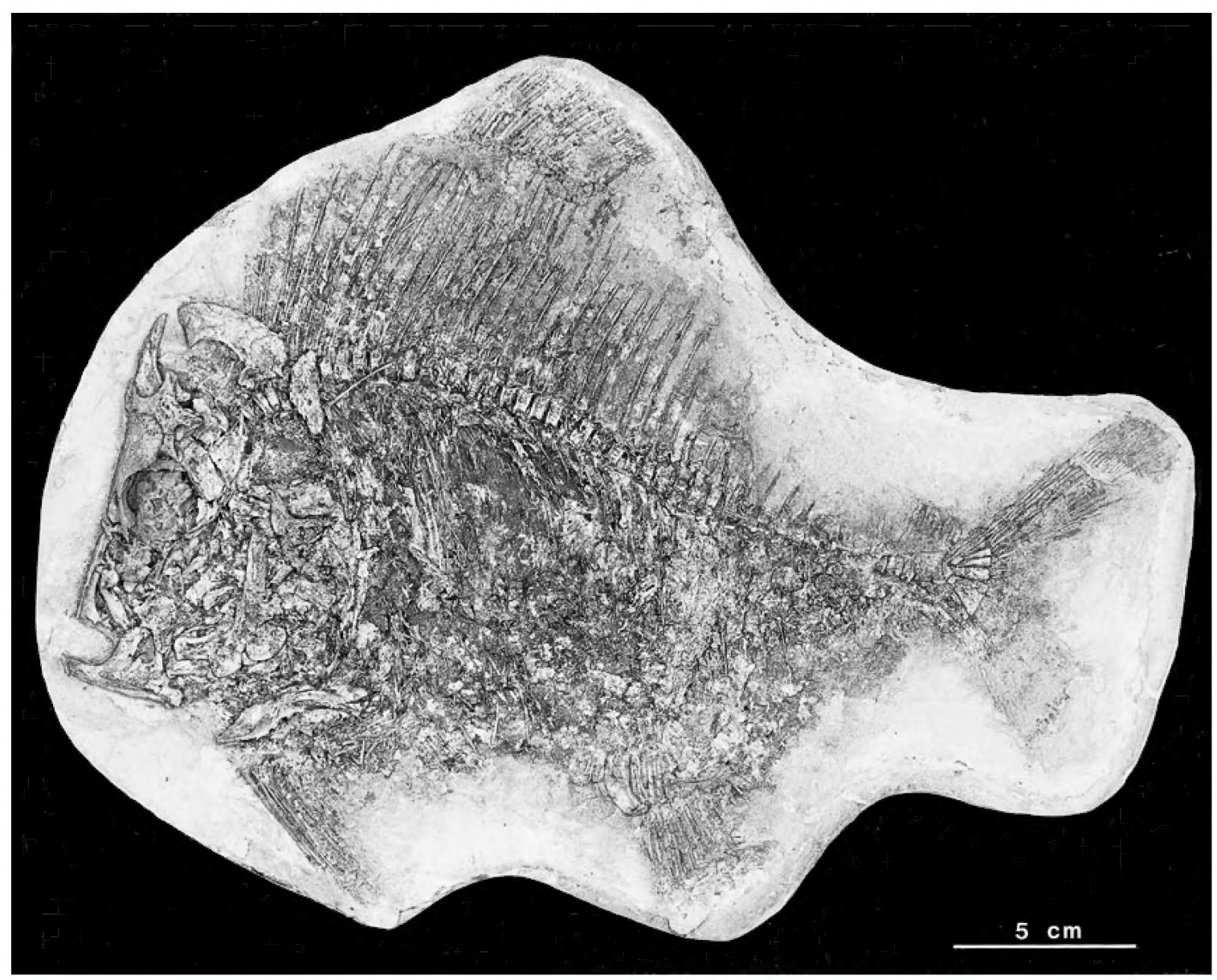

Fig. 4. Example of a complete Araripichthys castilhoi skeleton from the Santana Formation of Brazil, following preparation in acid (AMNH 13968).

tical series at deepest point above lateral line, 18-20 below; D:53; A:32; P:12+; V0).

Within the revised concept of the genus presented here, three species are distinguished. Cavin (1997a, 1997b) noted differences between Araripichthys corythophorus and A. castilhoi in the size and extent of the epioccipital and in the arrangement of circumorbital bones. The shape of the posterior skull margin differs in all three species, particularly the shape of the parietal and pterotic margins (fig. 5). These are much straighter in the Moroccan form than in either A. castilhoi or A. axelrodi. In A. castilhoi, the parietal posterior margin has a distinctly angular profile just above the pterotic, a feature that may be correlated with deepening of the subepiotic fossa. The epioccipital separates the subepiotic fossa (which lies medially) from the posttemporal fossa (which lies laterally), but its exposed lateral margin appears smaller in $A$. axelrodi and $A$. corythophorus than in A. castilhoi. The parietal posterior margin is marked by a distinct process in $A$. castilhoi and (to a lesser extent) in A. axelrodi. Unfortunately, the collective extent of variation in epioccipital shape in Araripichthys encompasses practically the entire range of that seen in other elopomorph fishes, and the primitive condition is uncertain. For example, in Tarpon, Notelops brama, and Rhacolepis buccalis the epioccipital forms a distinct posterior process, whereas in Elops and Osmeroides latifrons it is less prominent (Forey, 1973).

The identity of the bone Cavin (1997a: fig. 1.9) called the antorbital in Araripichthys corythophorus is problematic because the 

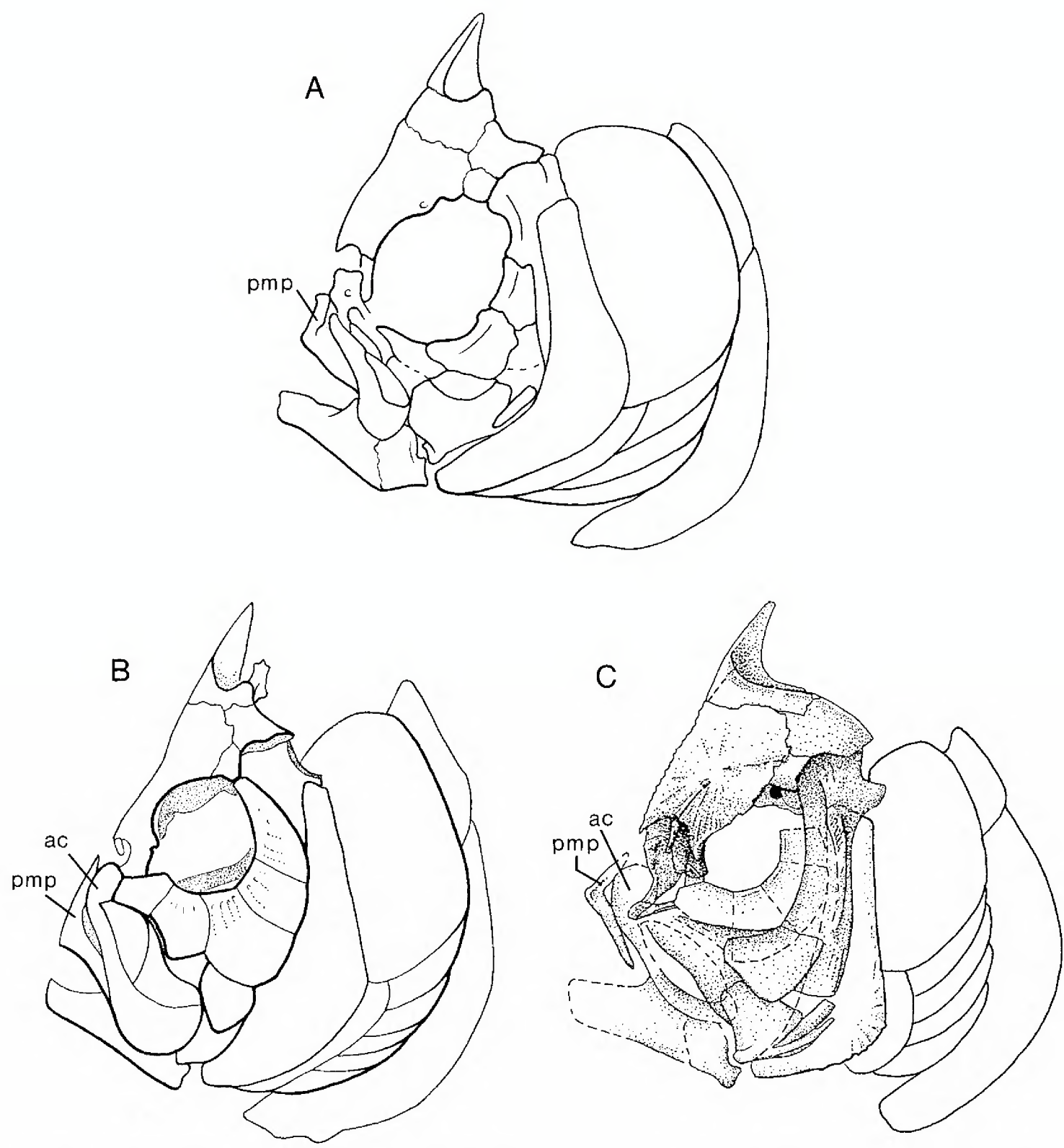

Fig. 5. Outlines of the head region in (A) Araripichthys axelrodi (as preserved), (B) Araripichthys castilhoi (reconstructed, from Maisey and Blum [1991] but omitting the supratemporal and posttemporal shown in their illustration), and (C) Araripichthys corythophorus from Morocco (as preserved; modified after Cavin). Note presence of more extensive premaxillary process and articular condyle on maxilla in parts $\mathrm{B}$ and $\mathrm{C}$.

antorbital is not known in the other species and because the circumorbital series is incompletely preserved in the Moroccan form. Cavin (1997a) identified a series of five bones (antorbital plus four infraorbitals) in $A$. corythophorus, the same number as in the infraorbital series of $A$. castilhoi, but in his illustration (fig. 5C here) he shows a gap that may have been occupied by the dermosphenotic (identified as the last infraorbital by Maisey and Blum, 1991). Thus, the circumorbital series in Araripichthys may have included an antorbital (unknown in A. castilhoi), followed by three infraorbitals and a 
dermosphenotic (not known in A. corythophorus). Alternatively, the "antorbital" of $A$. corythophorus may correspond to the first infraorbital in A. castilhoi (Maisey and Blum, 1991: 210 ; = lachrymal of Silva Santos, 1985a: pl. III), while its last "infraorbital" may represent an incomplete dermosphenotic, in which case the circumorbital series may have consisted of four infraorbitals plus the lachrymal. No supraorbital has been identified in any species of Araripichthys. A single anamestic suborbital has been identified in $A$. castilhoi, but it has not been found in the other species.

\section{PHYLOGENETIC AND BIOGEOGRAPHIC RELATIONSHIPS}

The maxilla is excluded from the superior border of the mouth in all three species of Araripichthys (figs. 2-6), but the suspensorial arrangement of $A$. axelrodi is apparently the least specialized of the three taxa. In $A r$ aripichthys axelrodi the ascending process of the premaxilla is certainly weaker than in $A$. castilhoi. In the type specimen of $A$. corythophorus the ascending process is broken, but as restored by Cavin (1997a) the process was long. The maxilla has a condyle and a rodlike anterior process in both $A$. castilhoi and $A$. corythophorus, but neither seems to be present in A. axelrodi (cf. figs. 3, 6). Presence of a strong premaxillary ascending process and a maxillary condyle are unusual features for a nonacanthomorph elopocephalan (Maisey and Blum, 1991); indeed, it was partly this elaboration of the jaws in Araripichthys that originally led Silva Santos $(1983,1985 a)$ to suggest it as a primitive acanthomorph.

On the basis of these slight differences in jaw morphology, Araripichthys castilhoi and $A$. corythophorus are hypothesized to be more closely related to each other than to $A$. axelrodi from Venezuela (fig. 7A). The deeply emarginated shape of the posterior skull roof (formed by the epioccipital and parietal) in $A$. castilhoi and $A$. axelrodi is regarded tentatively as a plesiomorphic similarity, while the straighter margin in A. corythophorus may represent an autapomorphy of that species. Alternatively, if the straight posterior margin of the posterior skull roof is regarded as a primitive condition, the polarity of this character would be reversed, and the deep emargination would then unite $A$. castilhoi and A. axelrodi. There are several other distinctive and unusual morphological features of $A$. castilhoi that at present cannot be compared in one or both of the other species.

The stratigraphic range of the family Araripichthyidae extends from the Aptian to the Turonian. According to the phylogenetic hypothesis presented here (fig. 7A), the earliest form is also the most primitive. The minimum age for the origin of Araripichthys is lower Aptian (approx. 124 mybp), while divergence of $A$. castilhoi from the hypothetical lineage leading to $A$. corythophorus dates from at least the lower Albian (112 mybp). An area cladogram based on these relationships shows Venezuela as a sister area to Brazil (Araripe basin) and Morocco (fig. 7B). At present, the most plausible paleobiogeographic scenario is that Araripichthys originated in the Pacific or western Tethys during the Aptian or slightly earlier and spread subsequently southeastward (either along the southern margin of Tethys or via an epicontinental seaway), reaching NE Brazil by the Albian and Morocco by the Turonian.

\section{INTERRELATIONSHIPS OF THE ARARIPICHTHYIDAE}

The phylogenetic relationships of the Araripichthyidae have not been clearly established. When Araripichthys was first described, it was identified as a beryciform, which would make it the earliest known acanthopterygian (Silva Santos, 1983, 1985a). In subsequent studies, however, the genus has been relegated to a lower phylogenetic position within teleosts (e.g., as Elopocephala incertae sedis; Maisey and Blum, 1991; Cavin, 1997a) principally because its caudal fin skeleton resembles that of other generalized elopocephalan fishes and it lacks apomorphic characters found in higher teleosts (fig. 8). Patterson (1993: 627) suggested that Araripichthys is a pachyrhizodontid, despite many profound differences (especially in its body form and jaws) from other pachyrhizodontids such as Rhacolepis, Pachyrhizodus, Greenwoodella, and Goulmimichthys. Cavin (1997a: 67) compared pachyrhizodon- 


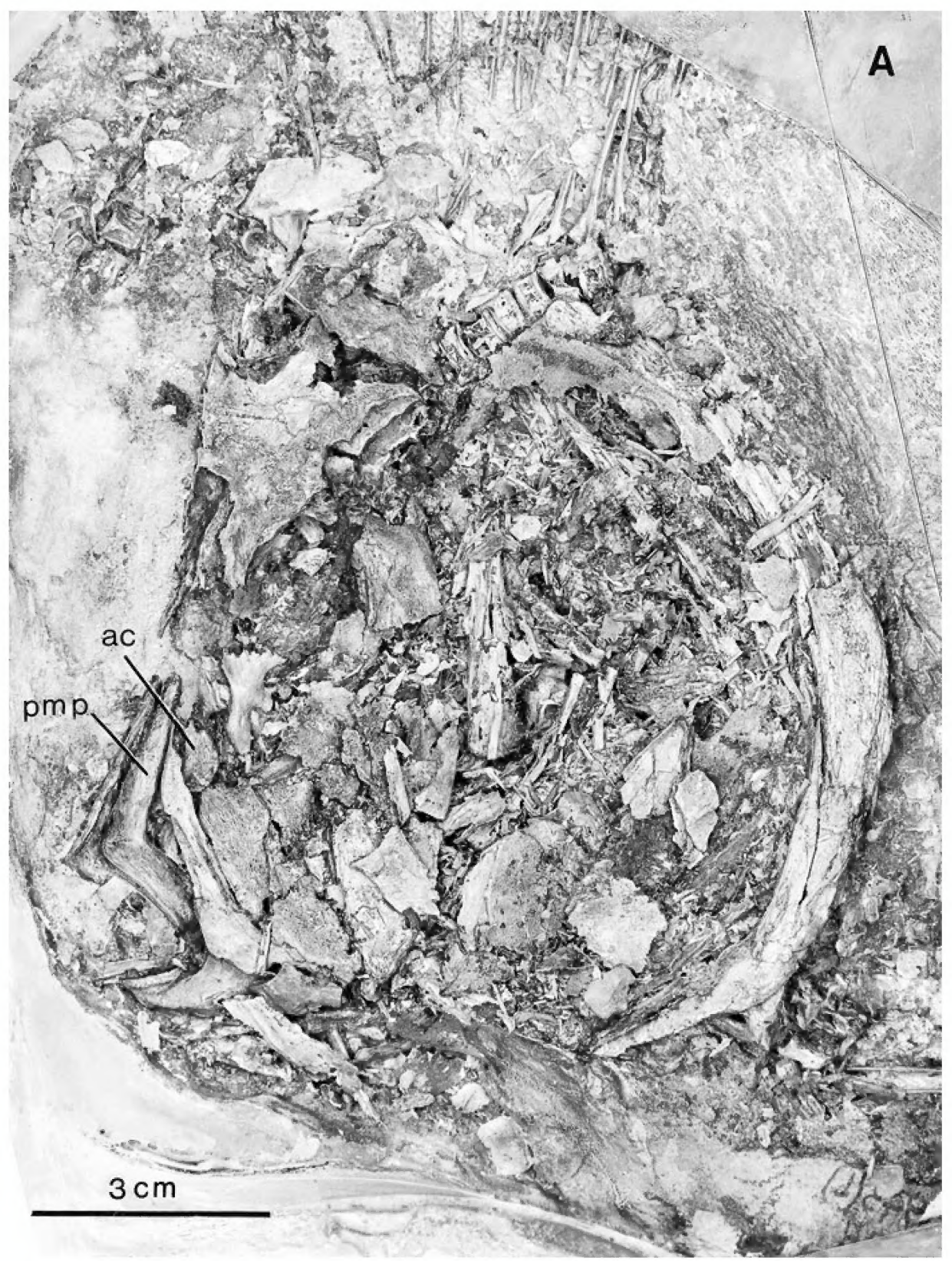

Fig. 6. Detail of the head in two acid-prepared specimens of Araripichthys castilhoi from the Santana Formation of Brazil showing the well-developed premaxillary process and articular condyle on maxilla. (A) AMNH 11943; (B) AMNH 13968 (compare with fig. 3).

tids and araripichthyids but was unable to identify any apomorphic characters with which to unite them as a monophyletic group.

Silva Santos (1985a) claimed that several supposed beryciform or acanthopterygian characters are present in Araripichthys, including presence of spiny rays in the dorsal and anal fins; a stegural (first uroneural with an anterodorsal outgrowth of membrane bone; an elevated occipital crest; absence of supraorbitals; presence of a mobile, sliding premaxilla with an extensive ascending process; modified maxillary-vomerine articulation; exclusion of the maxilla from the superior margin of the mouth; and absence of 


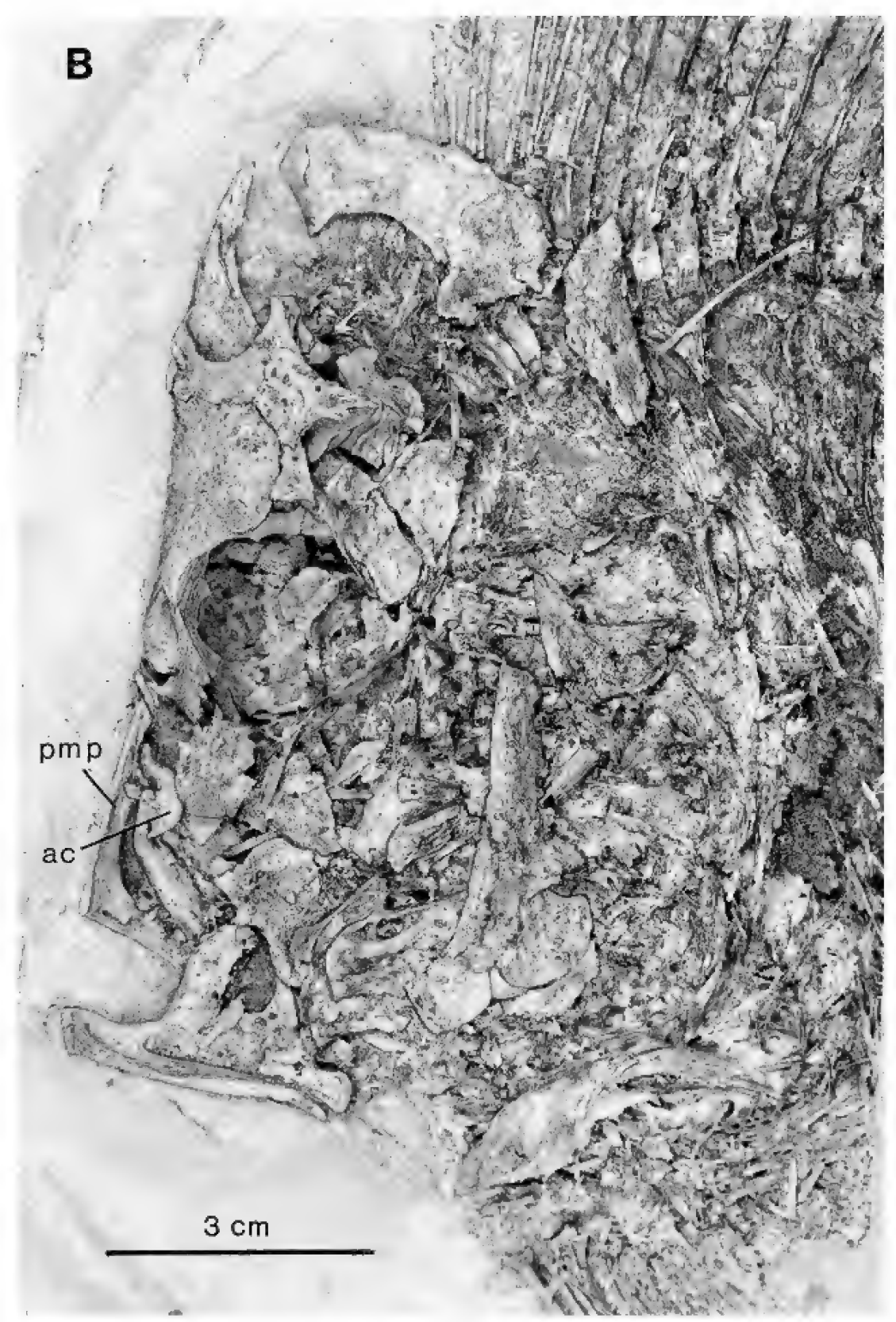

Fig. 6. Continued.

pelvic fins. Unfortunately, most of these features are not acanthomorph synapomorphies and were discarded as characters uniting $A r$ aripichthys and acanthomorphs by Maisey and Blum (1991: 215). They suggested, however, that the absence of pelvics and those characters involving the jaws offer "tempting but not compelling support for a relationship" between Araripichthys and lampri- diforms, and that lampridiforms may have arisen from basal acanthopterygians "prior to the major radiation of the group during later Cretaceous and Early Tertiary times." Only the more derived modern lampridiform taxa (i.e., those with a ribbonlike body form) lack pelvics, however, whereas these are present in more basal members of the group. Pelvics are also absent in modern eels, as 

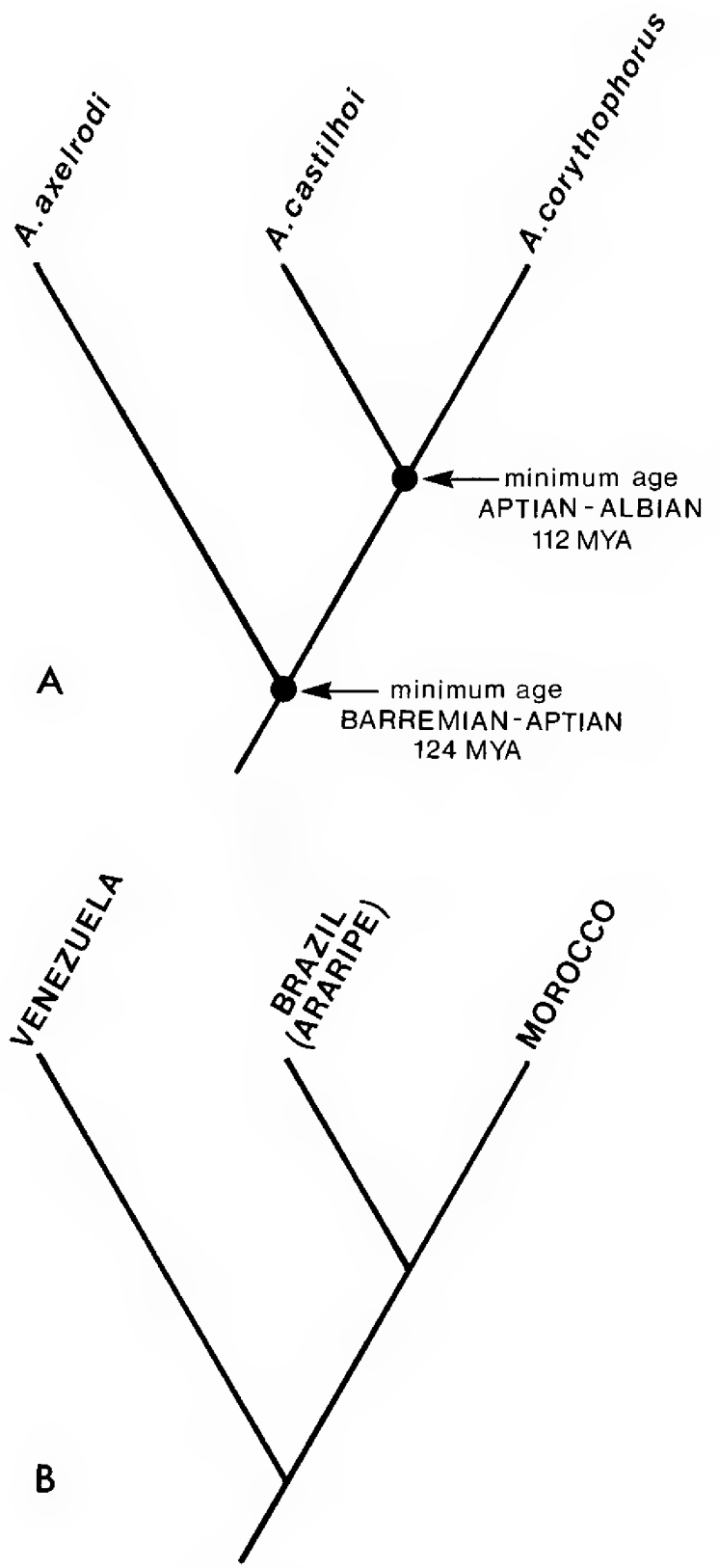

Fig. 7. (A) Phylogenetic relationships and minimum dates for divergence in Araripichthys; (B) areal relationships based on phylogeny.

well as in many tselfatioids. Thus, the phylogenetic position of Araripichthys is unresolved even quite fundamentally within teleosts, and therefore presents a situation that invites further discussion.

1. Is Araripichthys related to the Ferrifronsidae?
Acanthichthys and Ferrifrons are two late Cretaceous teleosts from North America. According to Arratia and Chorn (1998), Acanthichthys and Ferrifrons are closely related, and both these genera were placed within a new family Ferrifronside. They also identified three of Johnson and Patterson's (1993) acanthomorph characters in Acanthichthys (characters 1,6 and 7; that is, spiny dorsal fin-rays, with the condition in the anal fin being unknown; medial pelvic process ossified medially; and first vertebral centrum with facets for exoccipitals). Far less evidence exists to place Ferrifrons within acanthomorphs. Arratia and Chorn (1998) identified spiny fin-rays in the anal fin, but the dorsal fin is unknown, as are the pelvics (which are assumed, by comparison with Acanthichthys, to have been positioned in an abdominal position, although one could just as readily argue that they were absent, as in Araripichthys). No other acanthomorph characters listed by Johnson and Patterson (1993) were documented by Arratia and Chorn (1998) in Ferrifrons.

Arratia and Chorn (1998: 313) found differences between Acanthichthys and Araripichthys that "clearly separate both genera." They did not explore the possibility of a relationship between Araripichthys and Ferrifronsidae any further, but instead side-stepped the issue by reiterating the opinions of Maisey and Blum (1991) and Patterson (1993) that Araripichthys is not an acanthomorph. Both Ferrifrons and Acanthichthys nevertheless resemble Araripichthys in their general body form, sinusoidally curved vertebral column, head with a steeply sloping frontal region, presence of exoccipital facets in the occipital region, shape and arrangement of mouthparts (especially exclusion of the maxilla from the superior border of the mouth), edentulous jaws, expanded (compound?) first anal pterygiophore, and scales covering the bases of the dorsal and anal fins.

The occipital joint and pelvic process are both unknown in Ferrifrons, and the only putative acanthomorph-like feature identified by Arratia and Chorn (1998) is the presence of spiny fin-rays in the anal fin. Although they claimed that Araripichthys differs from the Ferrifronsidae in lacking median fin spines and pelvic fins, in fact the anal fin is 


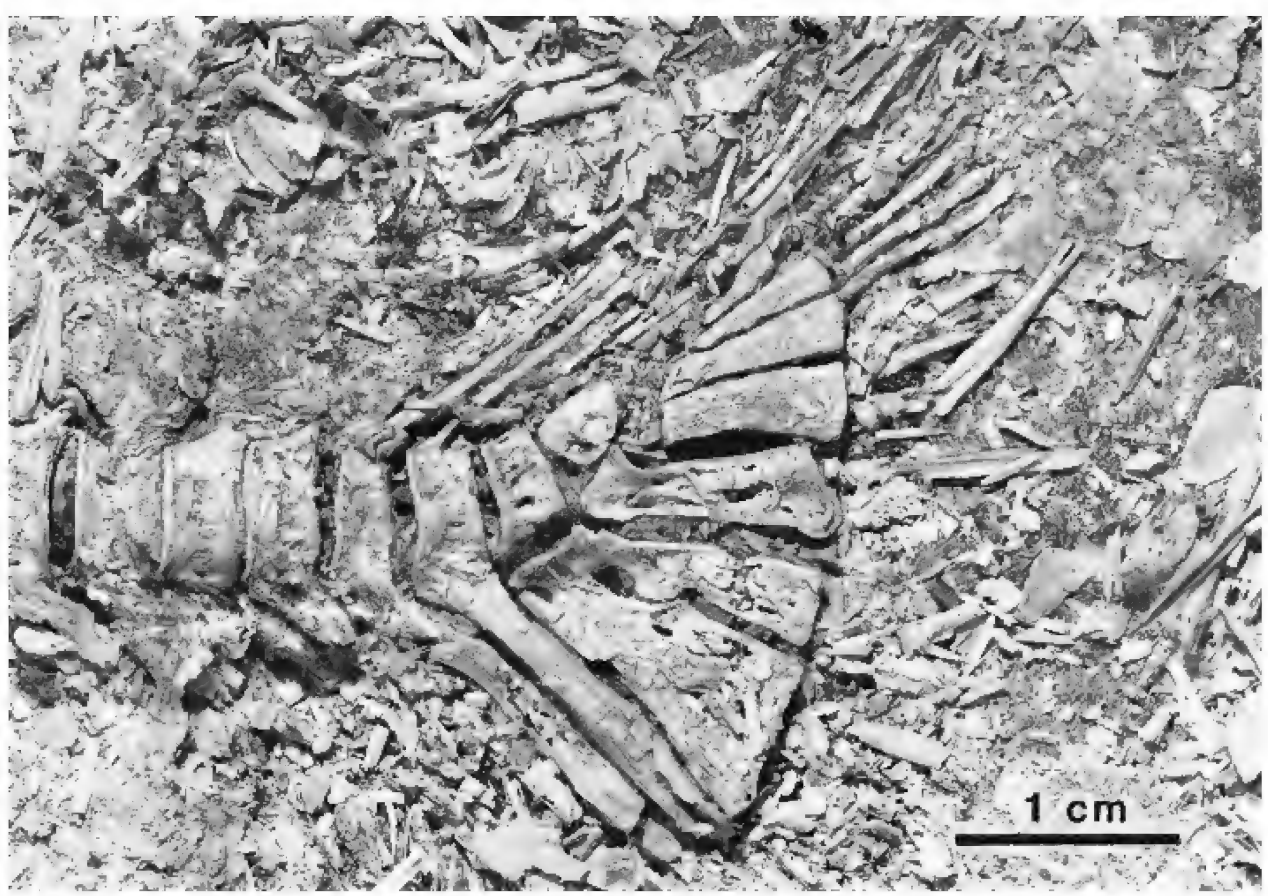

Fig. 8. Caudal endoskeleton in an acid-prepared specimen of Araripichthys castilhoi, AMNH 11944.

unknown in Acanthichthys, and the pelvics and dorsal fin are unknown in Ferrifrons, so the supposed difference has not yet been convincingly demonstrated. True fin spines are unsegmented median structures, with no trace of fusion between left and right lepidotrichia. Dorsal and anal spines with a median internal cavity not only occur in acanthopterygians, but also in notacanths and the otophysan Lipogenys (Johnson and Patterson, 1993). The presence of these spines is therefore not a reliable indicator of acanthopterygian affinity.

Scale morphology supposedly differs in Araripichthys and Ferrifronsidae (Arratia and Chorn, 1998). In Araripichthys, the scales are almost all cycloid, whereas both Acanthichthys and Ferrifrons have spinoid scales (sensu Roberts, 1993). Nevertheless, this distinction is reduced by the observation that, in the region between the pelvic and anal fins of Acanthichthys, the scales also "seem to be cycloid" (Arratia and Chorn, 1998: 309). While the presence of spinoid scales may unite Acanthichthys and Ferrifrons, it does not clearly distinguish them from Araripichthys.

The presence of a tripartite occipital ar- rangement (in which the exoccipitals are incorporated into the occipital joint, with distinct facets for the first vertebra) was regarded by Arratia and Chorn (1998) to be an important character uniting Acanthichthys and acanthomorphs. A similar arrangement is clearly present in Araripichthys (at least in the type species). While the tripartite occipital condyle in Araripichthys and Acanthichthys is similar to that of neoteleosts, its value as an acanthomorph character is questionable. Separate articular facets are present on the exoccipitals of salmoniform teleosts (e.g., Thymallus; Norden, 1961), and Rosen (1985) also recognized a tripartite occipital arrangement involving the exoccipitals in non-neoteleostean teleosts, noting that in many cases the appearance is related to fusion between the first vertebral centrum and basioccipital. He also noted Patterson's (1975: 318) suggestion that growth of an "osteoid plug" within the notochordal canal of the basioccipital in pholidophorids is responsible for excluding the exoccipitals from the posterior face of the occiput.

These findings collectively led Rosen (1985: 11) to propose that "the tripartite arrangement of bones on the posterior face of 
the braincase is a primitive feature that has been restored in neoteleosts and some primitive euteleosts by a means so far unknown." Rosen (1985: 14) concluded that "the tripartite joint of neoteleosts is a very old feature and the primitive and widespread presence of an accessory neural arch is inferred to be the remains of an ontogeny that had incorporated vertebral fusion with the occiput." Actually, there is some paleontological support for even greater antiquity, because a similar tripartite arrangement also occurs sporadically outside teleosts, for example in some extinct halecomorphs (e.g., Oshunia, "Aspidorhynchus"; Maisey, 1999: figs. 1, 12).

Rosen (1985: 22) nevertheless also outlined a phylogenetic-developmental scenario for the origin of the triple joint in acanthomorphs, involving several presumably derived and successively acquired characters, which included (1) development of a gap between occiput and first centrum, and exposure of exoccipitals and basioccipital as attachment or articular surfaces; (2) loss of accessory neural arch (all myctophoids and acanthomorphs); (3) ligamentous attachment of exoccipitals to dorsolateral part of first centrum; (4) extension of exoccipitals into this ligamentous network, accompanied by growth of autocentral prezygapophyses and closure of gap between basioccipital and first centrum; and (5) bone-to-bone condylar articulations between occiput and facets on first centrum.

Collectively, these observations, interpretations, and scenarios only seem to compound the problem; a tripartite occipital joint may be a primitive teleostean (or halecostome) character, which may show up as an occasional homoplasy within teleosts, yet in neoteleosts several apparently apomorphic features of the joint are distinguishable. It remains to be seen if some or all of these supposed derived features are absent in non-neoteleosteans possessing a triple occipital joint, and unfortunately no ontogenetic data are available for the fossils.

There are, however, paired prezygapophyses on the anterior neural arches in $A r$ aripichthys castilhoi. These appear to be functionally similar to (although perhaps not homologous with) the autocentral prezyga- pophyses of acanthomorphs (Rosen, 1985) in bracing the occipital connection.

\section{Quo vadis Araripichthys?}

Acanthomorph fishes are nested within successively less generalized teleostean taxa (e.g., clupeocephalans, euteleosts, neoteleosts), so if Araripichthys and/or Acanthichthys are acanthomorphs, they should also possess apomorphic characters of the wider groups to which acanthomorphs belong. Some of these characters, together with their sources in the literature, are listed below (see appendix 1). Inspection of this list reveals how difficult it is to place Araripichthys and Acanthichthys within these groups, because many of their diagnostic characters involve soft tissues or anatomical details that are rarely preserved in fossils (e.g., branchial arch morphology). Even among the remaining osteological characters, however, Araripichthys displays a remarkably uneven variation.

Araripichthys lacks three of the four clupeocephalan characters listed by Patterson and Rosen (1977) (i.e., retroarticular excluded from jaw joint; angular fused to articular or retroarticular; presence of a stegural). The fourth character, involving the absence of a neural arch on the first ural centrum, is shared by Araripichthys and clupeocephalans (fig. 8). Arratia (1996) further subdivided this character by distinguishing between presence or absence of the neural spine and neural arch of the "first" ural centrum. Thus, Araripichthys has the putative derived state (absence) for both of its characters (as does Acanthichthys; Arratia and Chorn, 1998). In Acanthichthys, the retroarticular and angular bones have not been described, nor has the stegural, although the first ural centrum apparently lacks a neural arch.

Euteleosts have been recognized as a monophyletic group since the work of Greenwood et al. (1966). The five characters uniting euteleosts in appendix 1 are a composite of those used by Patterson and Rosen (1977) and Johnson and Patterson (1996). Importantly, Euteleostei of Johnson and Patterson (1996) is a different usage from that of Patterson and Rosen (1977) in excluding Ostariophysi, and characters used to support 
euteleost monophyly in these works are not the same. For the present purposes, however, these differences are less important than the fact that none of the characters has been identified with certainty in either Araripichthys or Acanthichthys, although three of them involve "soft" structures (adipose fin, nuptial tubercles, caudal median cartilages). It nevertheless seems unlikely that Araripichthys or Acanthichthys had an adipose fin; in both genera, the dorsal fin is extensive and it occupies virtually the entire dorsal margin back to the tail. Presence of the adipose fin is regarded as an euteleost character (Patterson and Rosen, 1977), but it is almost universally absent in acanthomorphs, and according to Johnson and Patterson (1996) it is also secondarily absent in esocoids. The adipose fin may have been repeatedly lost in higher teleosts, and its absence in Araripichthys and Acanthichthys is therefore phylogenetically uninformative. Two of the euteleostean characters involve skeletal morphology; one has not been determined in Araripichthys or Acanthichthys (supraneural pattern), and the other seems to be absent (stegural not meeting opposite member at midline).

Neoteleostean fishes are characterized mainly by a specialized pharyngeal retractor muscle and associated modifications to the gill arches (Rosen, 1973; Lauder and Liem, 1983). Neoteleosts were first diagnosed as monophyletic by Rosen (1973) on the basis of three characters (retractor dorsalis muscle, presence of ascending and articular premaxillary processes, and features of the mandibular adductor muscle). The last two characters were rejected by Fink and Weitzman (1982), but they retained the retractor dorsalis muscle and added three more characters supporting neoteleost monophyly; that is, presence of rostral cartilage, "type 4" tooth attachment (sensu Fink, 1981), and articulation of both exoccipitals and basioccipital with vertebral column. Rosen (1985) subsequently revisited neoteleostean monophyly and listed three apomorphic characters-the retractor dorsalis, exposure of the exoccipitals as part of the posterior occipital outline and joined to basioccipital by an inverted Yshaped suture, and presence of an interoperculohyoid ligament.
Johnson (1992) reviewed all these earlier works and accepted four of the characters supporting neoteleosts (see appendix 1). As far as fossils are concerned, two of these characters involve the pharyngeal musculature and cannot be determined in Araripichthys or Acanthichthys, and a third is not applicable ("type 4" tooth attachment; both Araripichthys and Acanthichthys are edentulous). The fourth character (exoccipital and basioccipital exposed posteriorly, with inverted "Y" suture) is present in Araripichthys, but this part of the braincase has not been described in Acanthichthys.

Johnson and Patterson (1993) identified several apomorphic characters of acanthomorphs, including (1) azygous, unsegmented, bilaterally fused anterior fin-rays in the dorsal and anal fins; (2) rostral cartilage (associated with the ascending process of the premaxilla); (3) absence of median caudal cartilages; (4) separate anterior and medial infracarinalis muscles; (5) dorsal limb of posttemporal closely bound to epioccipital; (6) medial pelvic process ossified distally; and (7) first centrum with anterior surface bearing distinct facets that articulate with exoccipital condyles. Of these characters, only 1,6 , and 7 are likely to be recognizable in fossils (Arratia and Chorn, 1998).

An additional character was identified by Stiassny (1986); (8) in acanthomorphs the ethmoid cartilage is reduced, and the lateral ethmoids are either closely associated or fused with the vomer. Johnson and Patterson (1993: 601) did not include this as a separate apomorphic character, and they noted that "it may well be correlated with the rostral cartilage, and so not be independent." While this may be true, the character has significance where fossils are concerned because proximity or fusion of the lateral ethmoids and vomer may be observed in fossils, even where the rostral cartilage is not preserved. Proximity or fusion of the lateral ethmoids and vomer may therefore provide a means of inferring the presence of the rostral cartilage in fossil acanthomorphs.

A large ascending premaxillary process is known to occur in various non-acanthomorph fishes, and this feature is not an acanthomorph synapomorphy; however, its presence in Araripichthys and Acanthichthys is 
nevertheless of interest because (i) it represents a highly derived state of jaw suspension, presumably related to functional protrusion and suction feeding analogous to that of higher teleosts, and (ii) in acanthomorphs the process is associated with the rostral cartilage (character 2 above). Unfortunately, the arrangements of ligaments associated with the process represent the apomorphic character in acanthomorphs, not presence of the process itself. The ascending process in acanthomorphs is associated with the derived features of the ethmoid region that permit the process to slide up and down. It is uncertain whether such a range of movement was possible in Araripichthys, although the premaxilla may have been capable of downward protrusion. Articular and postmaxillary processes are both absent in Araripichthys (figs. 3,6) and are unknown in Acanthichthys. The premaxilla excludes the maxilla from the oral margin anteriorly in both Araripichthys and Acanthichthys, but the maxilla still forms a considerable part of this margin farther posteriorly, unlike in many acanthomorphs.

It is concluded that four acanthomorph characters are potentially recognizable in fossils $(1,6-8)$, and one further character (2) is weakly suggested by the form of the ascending premaxillary process. Only one of these characters is unquestionably present in $A r$ aripichthys ( 7 , first centrum articulates with exoccipitals and basioccipital). The dorsal and anal fin-rays in Araripichthys are certainly spinelike (character 1 ), but removal of the anteriormost fin-rays from an acid-prepared specimen (AMNH 13968) confirms the assertion by Maisey and Blum (1991) that these are paired and unfused, and they do not therefore resemble the unpaired spines of acanthomorphs. Character 6 cannot be compared because the pelvic process is itself absent.

The exoccipitals and basioccipital articulate with the first vertebral centrum in $A$. castilhoi, as shown by the two acid-prepared specimens illustrated here. In one of these (AMNH 11948; fig. 9), the first vertebral centrum is fused with the basioccipital and also meets the exoccipitals via paired articular surfaces. In the other example (AMNH 13968; fig. 10), the vertebral column has become separated from the basioccipital, ex- posing the tripartite articular surface formed by the basioccipital and exoccipitals. The articular surfaces of the exoccipitals are angled at approximately $60^{\circ}$ to the basioccipital condyle. The articular surface resembles that of neoteleosts (Johnson, 1992). According to Arratia and Chorn (1998), Acanthichthys also possesses a tripartite occipital condyle involving the exoccipitals and basioccipital, and the first neural arch has prezygapophyses that articulate with the exoccipitals.

Within basal acanthomorphs, Johnson and Patterson (1993) identified four synapomorphies of Euacanthomorpha (= Acanthomorpha minus Lampridiformes). Two of these characters involve epineural bones (first epineural displaced ventrally into horizontal septum; point of origin of anterior epineurals displaced ventrally onto centra or parapophyses). Intermuscular bones (epineurals, epicentrals, epipleurals) have not previously been reported in Araripichthys, and Arratia and Chorn (1998) did not observe epineurals or epipleurals in Acanthichthys major, although they did report finding a few broken "epicentral-like bones" alongside the anterior vertebrae. Several epineurals are present in a specimen of A. castilhoi (AMNH 11948), where they are associated with the anteriormost neural arches (fig. 9). The epineurals in AMNH 11948 are in series with each other, and are directed dorsally and posteriorly. Each epineural has an expanded and branched proximal end, with a prominent dorsal process and smaller median and ventral processes (fig. 11). There is no evidence of epicentrals or epipleurals in the specimen. Unfortunately, in fossils there is no way to distinguish between absence of an intermuscular series (i.e., lacking ligaments as well as bones) versus absence of ossification.

The presence of epineurals is probably a primitive teleostean character (Patterson and Rosen, 1977; Johnson and Patterson, 1995; Arratia, 1996). Since the horizontal septum is not preserved in AMNH 11948, its relationship to the epineurals cannot be determined, but judging from the position of the epineurals (lateral to the neural arches) they probably did not descend into the septum. Primitive basal lampridiforms have epineurals at the base of the neural arch (not descended as in other acanthomorphs), so their 

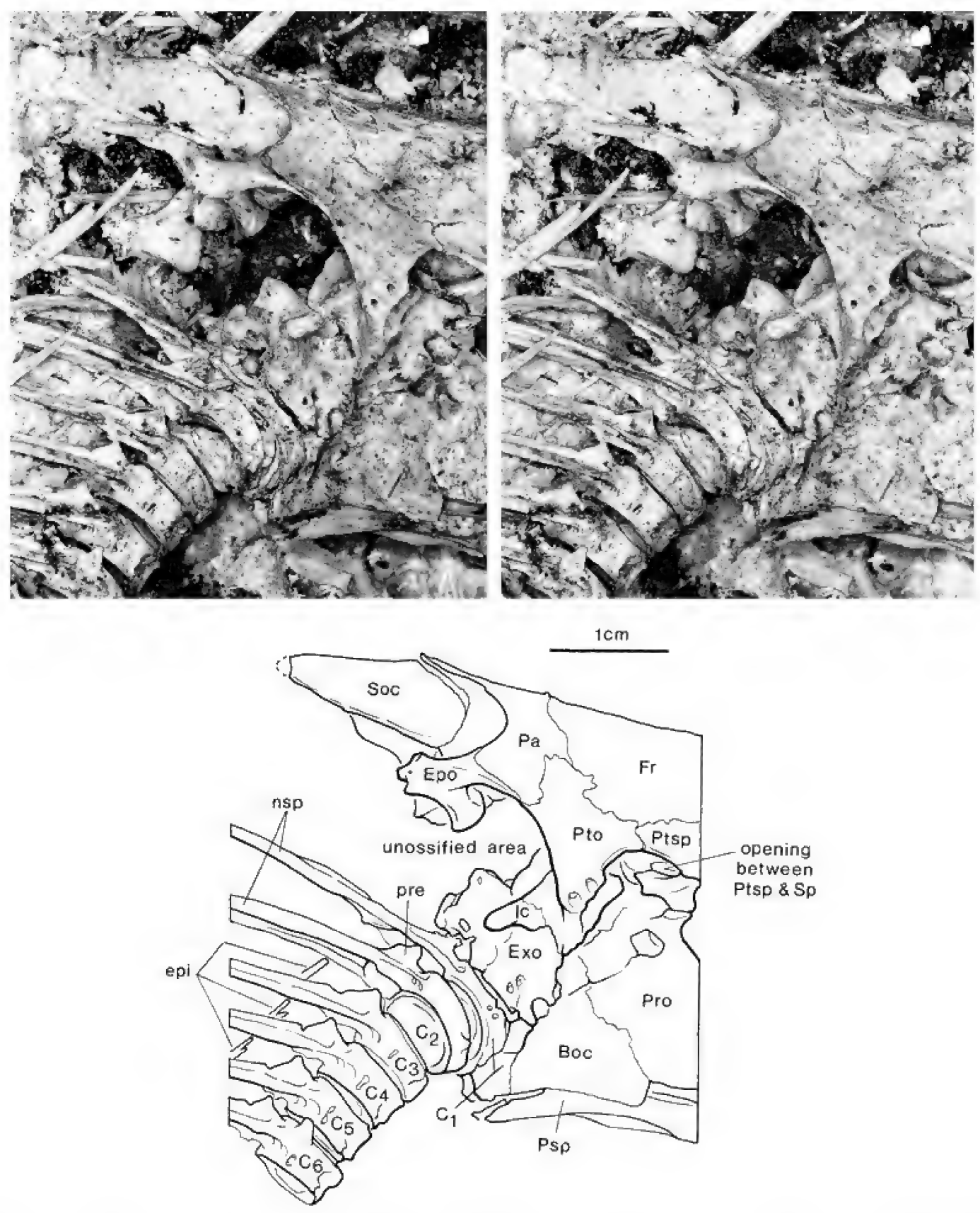

Fig. 9. Araripichthys castilhoi, AMNH 11948, Lower Cretaceous, Santana Formation, Brazil. Stereopair of acid-prepared occipital region (lateral view, right side). The first vertebral centrum is fused to basioccipital, but it is separated by a narrow gap from the exoccipitals, and the neural arch contacts the exoccipital above spinal nerve opening. Parts of three epineural bones of the left side are exposed between the anterior neural arches. Note also the presence of a wide unossified space between the supraoccipital and exoccipitals, as well as the round opening between the pterosphenoid and sphenotic connecting the orbit and dilatator fossa (both these features are also evident in fig. 10). 

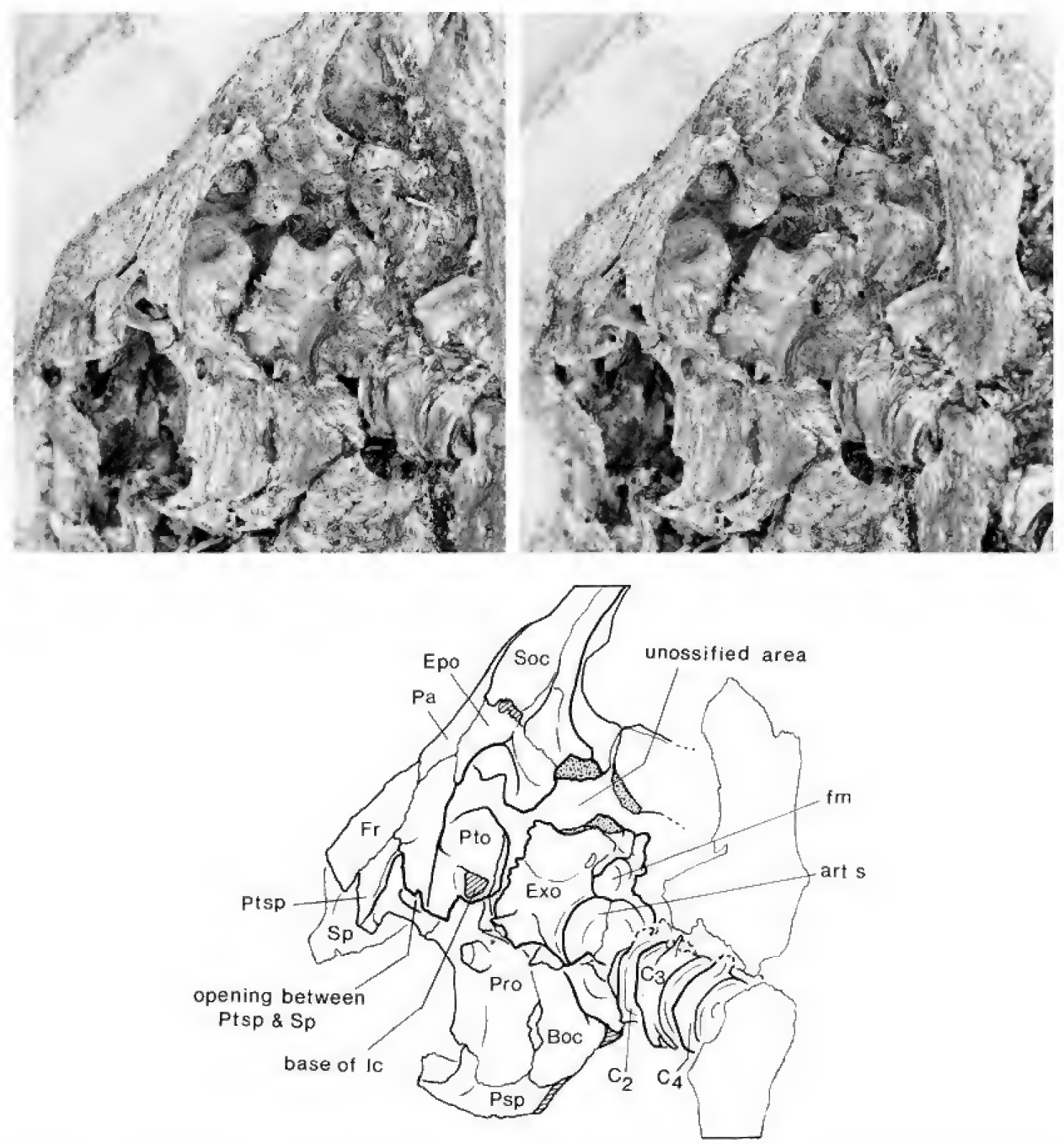

Fig. 10. Araripichthys castilhoi, AMNH 13968, Lower Cretaceous, Santana Formation, Brazil. Stereopair of acid-prepared occipital region (oblique posterolateral view, left side). The vertebral column has separated from the exoccipitals, revealing the tripartite occipital condyle involving the exoccipitals above the basioccipital articular surface. The intercalar has broken off in this specimen (it is intact in AMNH 11948; see previous figure). Note also that the supraoccipital does not reach the foramen magnum, which is enclosed by the exoccipitals. No scale; $\sim \times 1.8$.

position in Araripichthys castilhoi does not completely rule out an acanthomorph relationship. The branched proximal end is of interest, however, as no other acanthomorph has branched epineurals (G. D. Johnson, personal commun., June 2000).
A third euacanthomorph character recognized by Johnson and Patterson (1993) involves distal ossification of the posterior pelvic process. This character cannot be determined in Araripichthys, where the pelvic bone is absent, and the pelvic process has not 


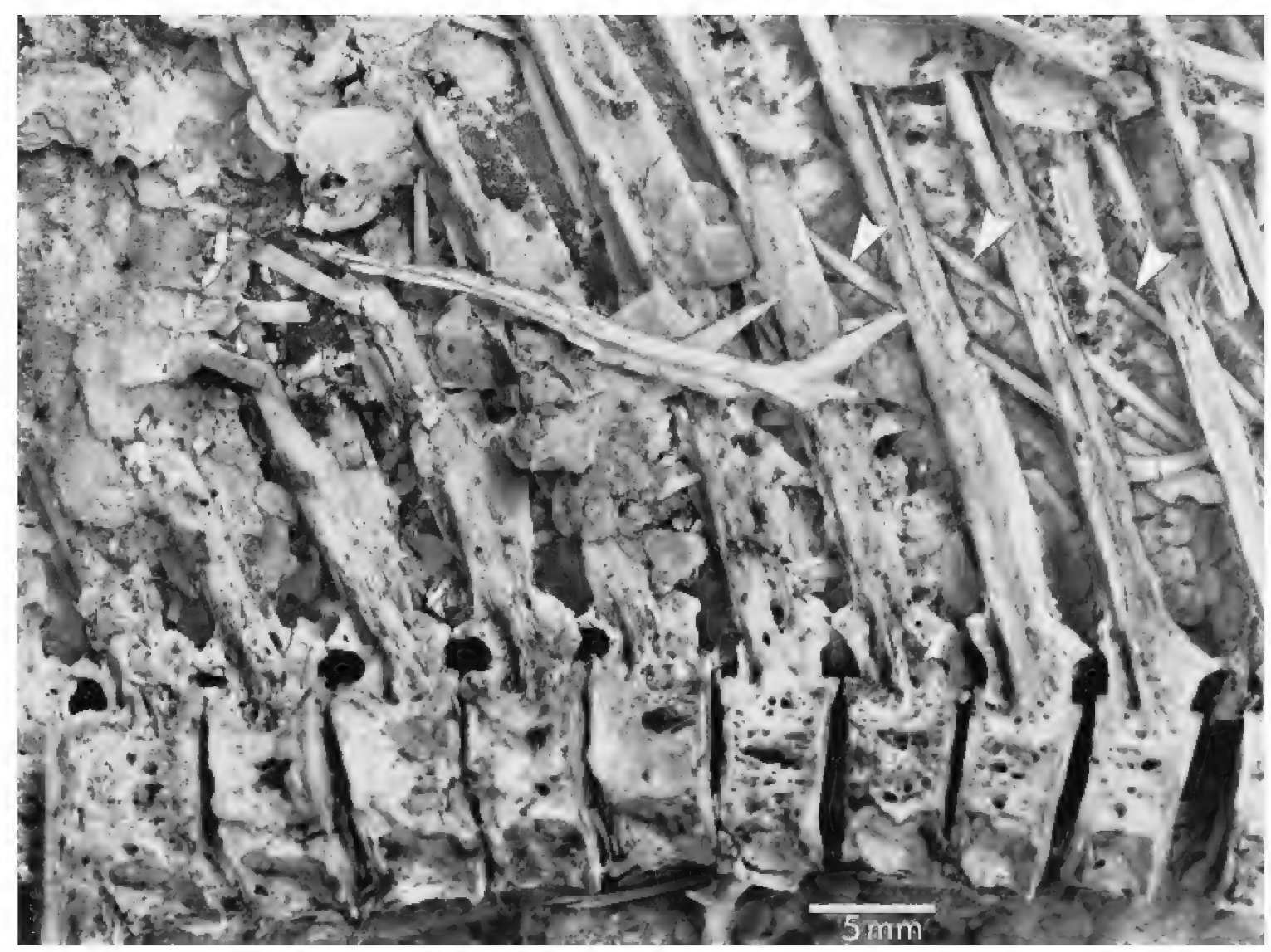

Fig. 11. Isolated right epineurals of Araripichthys castilhoi (AMNH 11948). Two epineurals are seen here, one overlying the other, both with branching proximal ends. Most of the other epineurals on this side have been lost, but those of the left side (arrowed) are still in place and can be seen between the neural arches.

been described in Acanthichthys. The fourth character recognized by Johnson and Patterson is the spina occipitalis (a ventral extension from the supraoccipital that extends to the foramen magnum; Stiassny, 1986); this last feature is absent in Araripichthys and probably in Acanthichthys. Stiassny (1986) regarded the presence of the spina occipitalis as a synapomorphy of her Acanthomorpha; however, the spina occipitalis is absent in all lampridiforms (Olney et al., 1993), and even within euacanthomorphs there is considerable variation in its extent (Johnson and Patterson, 1993).

Within euacanthomorphs, Johnson and Patterson (1993) also recognized three synapomorphies of Holacanthopterygii (= Euacanthomorpha minus Polymixiiformes). All three characters involve intermuscular bones: epipleurals are absent, epicentral ligaments are absent anteriorly, and distal (as well as proximal) parts of the anterior epineurals are displaced ventrally into the horizontal septum. Unfortunately we can only speculate about presence or absence of epipleurals and epicentral ligaments in Araripichthys, but its epineurals are not displaced ventrally.

Olney et al. (1993) found four characters uniting lampridiform fishes: absence of both an anterior palatine process and anterior palatomaxillary ligament, mesethmoid positioned posterior to the lateral ethmoids, premaxillary ascending process and rostral cartilage inserted into a frontal vault or cradle, and first dorsal pterygiophore inserted anterior to the first neural spine. None of these characters is present in Araripichthys, and none seems to be present in Acanthichthys or 
Ferrifrons. Thus, there is no morphological evidence of a relationship between lampridiforms and these extinct taxa.

While falling short of resolving the phylogenetic position of Araripichthys, this discussion at least airs a problem: What would a primitive stem acanthomorph look like, and how might we recognize it? Is Araripichthys an acanthomorph after all, as Silva Santos (1985a) first suggested, and is Acanthichthys an acanthomorph, as postulated by Arratia and Chorn (1998)? Is Acanthichthys primitively allied to Araripichthys, and what (if any) is the phylogenetic significance of the tripartite occipital condyle in these taxa? For the time being, there is insufficient evidence (i.e., number of characters) to support the inclusion of Araripichthys within acanthomorphs or even within neoteleosts. Given the morphological similarity of Araripichthys and other fossils such as Acanthichthys and Ferrifrons (especially in the occipital region and jaws), however, there is clearly a need to explore the question further. The possibility of a functional correlation between presence of protrusible mouthparts and bracing of the occipital region in deep-bodied teleosts needs careful analysis. This morphological combination is restricted today to acanthomorphs, but a similar pattern clearly may have existed in some extinct non-acanthomorphs.

The few neoteleostean and acanthomorph features found in Araripichthys may represent convergent similarities with those taxa. The presence of a cladistically primitive (elopocephalan-like) caudal fin morphology in Araripichthys is certainly congruent with that possibility. Even so, its phylogenetic placement within teleosts remains clouded by conflicting hypotheses of relationship among the crown group Teleostei (e.g., Patterson and Rosen, 1977; Arratia, 1996). As summarized in figure 12, for example, there is a fundamental disagreement regarding the relative phylogenetic positions of elopomorph and osteoglossomorph fishes. The elopocephalan group of Patterson and Rosen (1977) was supported by only a single character (presence of only two uroneurals). According to the original description of Araripichthys (Silva Santos, 1985a), two uroneurals are present, although this has not yet been confirmed from other material. On this admitted- ly tenuous basis, therefore, Araripichthys can be placed within Patterson and Rosen's (1977) scheme at an unresolved trichotomy with elopomorphs and clupeocephalans, but above osteoglossomorphs (fig. 12A). In Arratia's (1996) alternative hypothesis, Araripichthys can be placed at an unresolved trichotomy with stem elopomorphs and the stem osteoglossomorph-clupeocephalan clade (fig. 12B).

The complex morphological arguments surrounding this controversy will not be discussed further here, but note that of the six characters defending Arratia's (1996) grouping of osteoglossomorphs plus clupeocephalans (= her fig. 6A, node $\mathrm{J}$; see appendix 1), five seem to be present in Araripichthys and one is absent (the mandibular sensory canal emerges from behind the angular instead of laterally). Of six characters uniting Elops and Anaethalion in her analysis, four are absent, one is unknown, and another would require special pleading in Araripichthys (the mesethmoid supports a continuous ethmoid commissure as in Elops, but its shape and arangement are specialized; Maisey and Blum, 1991: 210, lower fig.).

Such ambiguity in the literature does little to help resolve the phylogenetic placement of problematic taxa such as Araripichthys. Conversely, however, extinct taxa such as Araripichthys and Acanthichthys highlight the need to develop a stable phylogeny of teleostean relationships. Araripichthys neither confirms nor contradicts the hypotheses offered by Patterson and Rosen (1977) or Arratia (1996), and it adds little to the controversy except that it divides the characters defining Arratia's (1996) osteoglossomorphclupeocephalan characters into two groups, so that one character (two uroneurals) or perhaps two (mesethmoid supports continuous ethmoid commissure?) may unite Araripichthys with her osteoglossomorph-clupeocephalan group.

Although the caudal and cranial skeleton of Araripichthys is more primitive than that of most euteleosts and acanthomorphs (Maisey and Blum, 1991), no synapomorphies have been found uniting Araripichthys with any particular elopocephalan group. Thus, its placement within the Elopocephala sensu Patterson and Rosen (1977) is just as prob- 

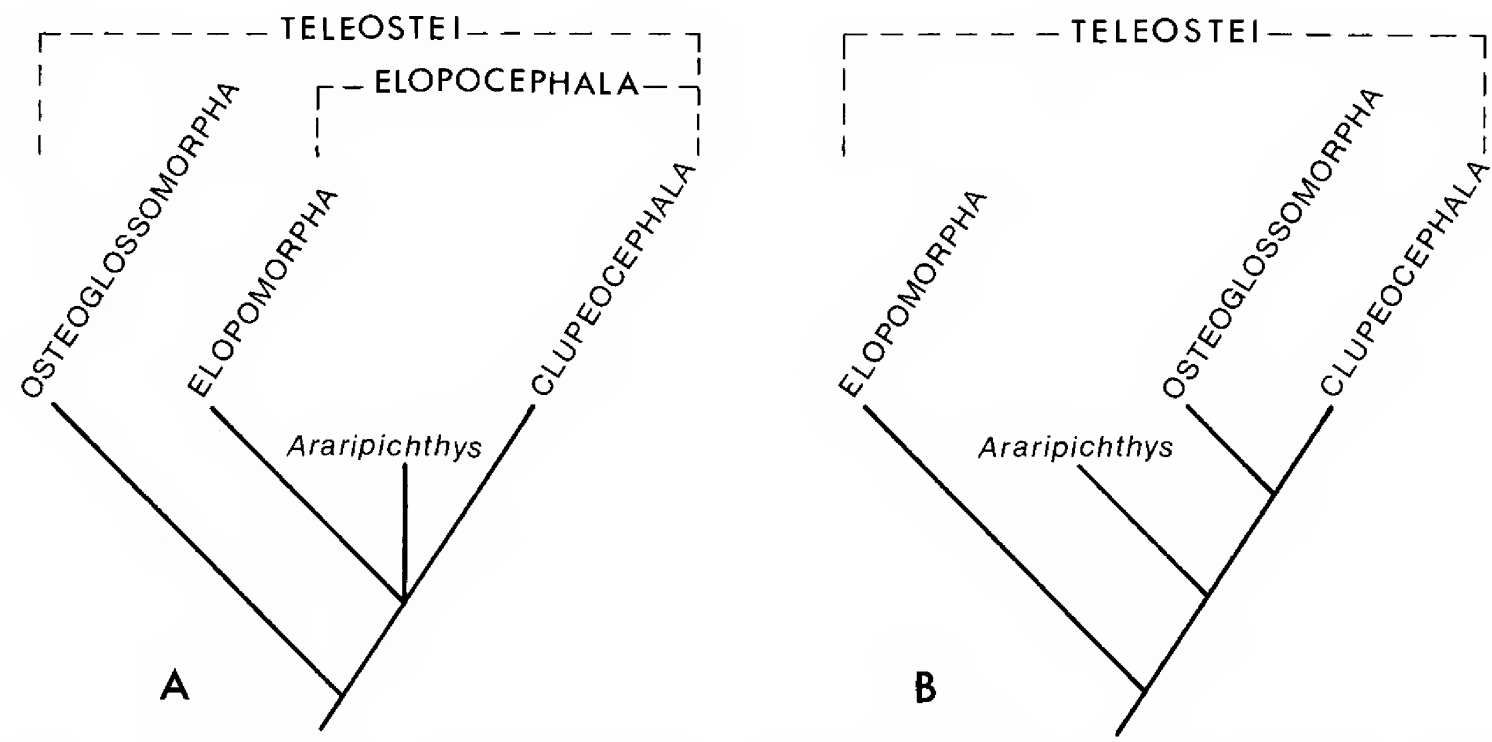

Fig. 12. The position of Araripichthys within two alternative phylogenies of teleost fishes (much simplified); (A) scheme of Patterson and Rosen (1977); (B) scheme of Arratia (1996).

lematic as its placement within neoteleosts. On the other hand, several features of Araripichthys (including the elongate premaxillary ascending process, protrusible maxilla, tripartite occipital condyle involving the exoccipitals, and prezygapophyses articulating with the exoccipitals) are shared with Acanthichthys as well as with neoteleosts (especially acanthomorphs). Araripichthys superficially resembles generalized lampridiforms and Upper Cretaceous acanthomorphs in its overall deep body form, and it resembles derived lampridiforms (but not more primitive ones) in lacking pelvics; in addition, Araripichthys primitively resembles lampridiforms in lacking the spina occipitalis.

To summarize, the dilemma is simply expressed, but not easily resolved. If Araripichthys is a primitive elopocephalan, any similarities with neoteleosts or acanthomorphs are presumably convergent; if it is an acanthomorph, it has retained an extremely high number of plesiomorphic characters. In either case, its relationship to other putative stem acanthomorphs such as Acanthichthys needs thorough and careful review. Inspection of appendix 1 shows the extent to which Araripichthys, Acanthichthys, and Ferrifrons share characters with higher teleostean groups. There is fairly strong support for including all three genera within elopocephal- ans or even clupeocephalans, but there is very little evidence that they belong higher within teleosts. No euteleost, eurypterygian, ctenosquamate, holacanthopterygian, or lampridiform characters were found in these fossils. Few characters support inclusion of $A r-$ aripichthys within neoteleosts or acanthomorphs (one character in each case). Two or perhaps three characters support Acanthichthys within acanthomorphs, and one questionable character supports inclusion of Ferrifrons in this group.

\section{DISTRIBUTION AND PALEOENVIRONMENT}

It is now well established that South America separated from Africa in stepwise fashion during the Late Jurassic and Early Cretaceous (Rabinowitz and LaBrecque, 1979; Reyment and Dingle, 1987; Szatmari et al., 1987; Popoff, 1988; Chang et al., 1992). Ammonites and especially foraminifers provide compelling evidence that a shallow but permanent equatorial seaway (in contrast with ephemeral "slop-overs") first appeared by the late Aptian and deepened progressively during the Albian (Beurlen, 1961; Berthou et al., 1997; Bengtson and Koutsoukos, 1991). Data from foraminifers suggest an initial influx of surface waters into 
the equatorial seaway from the western $(\mathrm{Ca}$ ribbean) part of Tethys (Koutsoukos, 1992). In addition, during mid-Cretaceous times there was a major global rise in sea level, leading to geographically extensive marine transgressions worldwide. An extensive interior sea probably covered large parts of South America during the mid-Cretaceous, with seaways extending from the Pacific across much of Brazil. At maximum extent, this sea probably linked the Pacific Ocean and the North and South Atlantic Oceans (Arai, 1999: fig. 1).

The distribution of marine fishes in western Gondwana would undoubtedly have been affected by such a major marine transgression. Its timing coincides with a sharp increase in the abundance and diversity of marine fish fossils in western Gondwana (Maisey, 2000). Some of the same taxa also occur in Australia (e.g., Vinctifer; Moody and Maisey, 1993), where an extensive mid-Cretaceous seaway also existed (Frakes et al., 1987; Campbell and Haig, 1999).

Both the Venezuelan and Moroccan occurrences of Araripichthys are from offshore marginal carbonate platform environments, which were fully marine, whereas the Araripe Basin of NE Brazil (the type locality of A. castilhoi) occupies an interior location within a small rift-bounded basin located on an aborted rift trend (Chang et al., 1992; Matos, 1992). Araripichthys (along with many other marine fishes) probably entered the Araripe Basin during an Albian marine pulse. Several taxa from the Santana Formation also occur in the Riachuelo Formation of the Sergipe Basin (an Albian marine platform deposit), including Rhacolepis, Notelops, Tharrhias, Vinctifer, Cladocyclus, and Neoproscinetes (Silva Santos, 1985a; Maisey, 2000), although Araripichthys has not yet been reported from there.

During the mid-Cretaceous there were only intermittent, but repeated, maritime connections within the Araripe Basin, generally increasing in both frequency and strength through time (Baudin et al., 1990; Berthou, 1990; Berthou, et al., 1990; Arai and Coimbra, 1990; Pons et al., 1990). The lower part of this sedimentary sequence also includes brackish, hypersaline (gypsiferous), and nonmarine deposits. Absence of many inverte- brate fossils (e.g., ammonites, belemnites, brachiopods, corals, sponges) and a paucity of others (e.g., echinoderms, crabs) in the Araripe Basin suggest it was marginal, with at best only tenuous connections to the epicontinental seaway postulated by Arai (1999). Fully marine conditions either were never developed in the Araripe Basin or were so ephemeral that marine sediments were not preserved. Sedimentary deposition within the basin was controlled by a northerly fault system associated with the Patos Lineament, and the basin was further separated from the northern end of the Recôncavo-Tucano-Jatobá rift trend by the Pernambuco Lineament.

Clearly, if further progress is to be made in unraveling the complex early biogeographic history of Caribbean Tethys and Equatorial Atlantic, more phylogenetic and biogeographic data are needed. Among other mid-Cretaceous fishes, candidates for future analysis and comparison include Rhacolepis and Vinctifer. In addition to the Colombian Rhacolepis there are also undescribed Rhacolepis-like pachyrhizodontids from Venezuela and Mexico, while Cavin (1995) has described Goulmimichthys arambourgi (a pachyrhizodontid closely related to Rhacolepis) from Morocco. The aspidorhynchid Vinctifer was widely distributed across (and beyond) the margins of western Gondwana and $\mathrm{Ca}-$ ribbean Tethys (Moody and Maisey, 1993; Schultze and Stöhr, 1996), but has not yet been reported from Morocco. Several species of Vinctifer are recognized (Brito, 1997) and await phylogenetic and biogeographic analysis.

\section{CONCLUSIONS}

1. The deep-bodied teleost Araripichthys has a stratigraphic range extending from the Aptian to the Turonian, and a geographic range that encompases the southern margin of the Tethys Ocean from Venezuela (its earliest occurrence) to Morocco (its youngest occurrence). Araripichthys from Venezuela, Brazil, and Morocco are sufficiently distinct from each other to merit species-level distinction.

2. Araripichthys axelrodi is the earliest and the most primitive representative of the genus, and it lacks some of the specializa- 
tions seen in the mouthparts of the other species. Araripichthys castilhoi from Brazil is more closely related to A. corythophorus from Morocco. The minimum age for divergence of the lineage including both the Brazilian and Moroccan forms is Albian.

3. The Venezuelan and Moroccan occurrences are from shallow epicontinental marine carbonate platforms, while the Brazilian A. castilhoi is from a restricted interior basin environment.

4. The biogeographic distribution of Araripichthys is concordant with foraminiferal data suggesting dispersal of taxa from Caribbean Tethys, but Araripichthys has not yet been documented within the Equatorial Seaway (e.g., from the Albian marine fish assemblage of the Sergipe Basin). Araripichthys may have entered the Araripe Basin following a mid-Cretaceous transgression from the west.

5. The systematic position of the Araripichthyidae within teleosts is unclear. Araripichthys shares some derived characters with the late Cretaceous Ferrifronsidae. Araripichthys could be an acanthomorph displaying a very high number of plesiomorphic characters. Alternatively, it may be a non-acanthomorph teleost, and the few derived characters it shares with acanthomorphs may have arisen independently in these taxa.

\section{ACKNOWLEDGMENTS}

This research project was supported in part by the Axelrod Research Chair in Paleoichthyology, funded by generous endowment from Dr. and Mrs. H. R. Axelrod. The acid preparation of fossils from Brazil was conducted by W. B. Elvers, I. S. Rutzky, and R. Evander, who also mechanically prepared the Venezuelan specimen. The illustrations were prepared by C. Tarka and L. Meeker.

\section{REFERENCES}

Arai, M.

1999. A transgressão marinha mesocretácea: sua implicacão no paradigma da reconstituicão paleogeográfica do Cretáceo no Brasil. 5 Simp. Cretáceo Bras.: $577-$ 582.

Arai, M., and J. C. Coimbra

1990. Análise paleoecológica do registro das primeiras ingressões marinhas na For- mação Santana (Cretáceo Inferior da Chapada do Araripe). Atas 1 Simp. Bacia do Araripe e bacias interiores do Nordeste, Crato: 225-239.

Arratia, G.

1996. Reassessment of the phylogenetic relationships of certain Jurassic teleosts and their implications on teleostean phylogeny. In G. Arratia and G. Viohl (eds.), Mesozoic fishes-systematics and paleoecology: 219-242. München: Verlag Pfeil.

Arratia, G., and J. Chorn

1998. A new primitive acanthomorph fish from the Greenhorn Formation (Late Cretaceous) of Nebraska. J. Vertebr. Paleontol. 18(2): 301-314.

Baudin, F., P.-Y. Berthou, J. P. Herbin, and D. A. Campos

1990. Matière organique et sedimentation argileuse dans le Crétacé du Bassin d'Araripe. Comparison avec les données du Crétacé d'autres bassins bresiliens. Atas 1 Simp. Bacia do Araripe e bacias interiores do Nordeste, Crato: 83-93.

Bengtson, P., and E.A.M. Koutsoukos

1991. Ammonite and foraminiferal dating of the first marine connection between the central and South Atlantic. 1 ${ }^{\text {er }}$. Colloque Stratigraphie et de Paleogeographie des bassins sedimentaires ouestAfricans, 11e Colloq. Afri. Micropaleontol. 1991, abstracts.

Berthou, P.-Y.

1990. Le Bassin d'Araripe et les petits bassins intracontinentaux voisins (NE du Brésil); formation et evolution dans le cadre de l'ouverture de l'Atlantique equatorial. Comparaison avec les bassins ouest-africains situes dans le même contexte. Atas 1 Simp. Bacia do Araripe e bacias interiores do Nordeste, Crato: 113-134.

Berthou, P.-Y., M. S. Lopes Teles, and D. A. Campos

1990. Sedimentation argileuse cretacée dans le bassin d'Araripe et quelques bassins annexes (NE du Brésil). Atas 1 Simp. Bacia do Araripe e bacias interiores do Nordeste, Crato: 143-162.

Berthou, P.-Y., F. Amedro, and I. M. Brito

1997. Revision bibiographique préliminaire a une étude des ammonites de l'Albien (Fm. Riachuelo) du Bassin de Sergipe (Nord Est du Brésil). Geociências, São Paulo 10: 183-190. 
Beurlen, K.

1961. Die Kreide im Küstenbereich von Sergipe bis Paraiba do Norte (Brasilien) Z. Dtsch. Geol. Ges. 112(3): 378-389.

Brito, P. M.

1997. Révision des Aspidorhynchidae (Pisces, Actinopterygii) du Mésozoïque: ostéologie, relations phylogénétiques, données environmentales et biogéographiques. Geodiversitas 19(4): 681772.

Campbell, R. J., and D. W. Haig

1999. Bathymetric change during Early Cretaceous intracratonic marine transgression across the northeastern Eromanga Basin, Australia. Cretac. Res. 20: 403446.

Cavin, L.

1995. Goulmimichthys arambourgi n.g., n.sp., un Pachyrhizodontidae (Actinopterygii, Teleostei) d'une nouvelle localité à nodules fossilifères du Turonien inférieur marocain. C. R. Acad. Sci. 321: 1049-1054.

1997a. Les actinoptérygiens du Turonien de Goulmima (Maroc) et l'évolution des ichthyofaunes actinoptérygiennes entre le Jurassique supérieur et le Paléocène. Ph.D. thesis, Univ. Paris, 1997, $218+$ vii pp.

1997b. Nouveaux Teleostei du gisement du Turonien inférieur de Goulmima (Maroc). C. R. Acad. Sci. 325: 719-724.

Chang, H. K., R. O. Kowsmann, A.M.F. Figueiredo, and A. A. Bender

1992. Tectonics and stratigraphy of the East Brazil Rift system: an overview. Tectonophysics 213: 97-138.

Fink, W. L.

1981. Ontogeny and phylogeny of tooth attachment modes in teleost fishes. J. Morphol. 167: 167-184.

Fink, W. L., and S. H. Weitzman

1982. Relationships of the stomiiform fishes (Teleostei), with a description of Diplophos. Bull. Mus. Comp. Zool. 150: $31-$ 93.

Forey, P.

1973. The osteology of Notelops Woodward, Rhacolepis Agassiz, and Pachyrhizodus Dixon (Pisces: Teleostei). Bull. Br. Mus. (Nat. Hist.), Geol. 28(2): 25-204.

Frakes, L. A., D. Burger, M. Apthorpe et al.

1987. Australian Cretaceous shorelines, stage by stage. Palaeogeogr. Palaeoclimat. Palaeoecol. 59: 31-48.
Greenwood, P. H., D. E. Rosen, S. H. Weitzman, and G. S. Myers

1966. Phyletic studies of teleostean fishes, with a provisional classification of living forms. Bull. Am. Mus. Nat. Hist. 131(4): 339-456.

Johnson, G. D.

1992. Monophyly of the euteleostean clades-Neoteleostei, Eurypterygii, and Ctenosquamata. Copeia 1992(1): $8-25$.

Johnson, G. D., and C. Patterson

1993. Percomorph phylogeny: a survey of acanthomorphs and a new proposal. Bull. Mar. Sci. 52(1): 554-626.

1995. The intermuscular bones and ligaments of teleostean fishes. Smithson. Contrib. Zool. 559: iv +83 .

1996. Relationships of lower euteleostean fishes. In M.L.J. Stiassny, L. R. Parenti, and G. D. Johnson (eds.), Interrelationships of fishes: 251-332. San Diego CA: Academic Press.

Koutsoukos, E.A.M.

1992. Late Aptian to Maastrichtian foraminiferal biogeography and palaeoceanography of the Sergipe Basin, Brazil. Palaeogeogr. Palaeoclimat. Palaeoecol. 92: 295-324.

Lauder, G. V., and K. F. Liem

1983. The evolution and interrelationships of the actinopterygian fishes. Bull. Mus. Comp. Zool. 150(3): 95-197.

Maisey, J. G.

1999. The supraotic bone in neopterygian fishes (Osteichthyes Actinopterygii). Am. Mus. Novitates 3267: 52 pp.

2000. Continental break-up and the distribution of fishes in Western Gondwana during the Early Cretaceous. Cretac. Res. 21: 281-314.

Maisey, J. G., and S. Blum

1991. Araripichthys. In J. G. Maisey (ed.), Santana fossils: an illustrated atlas, 208-217. Neptune NJ: TFH Publications.

Matos, R.M.D. de

1992. The north-east Brazilian rift system. Tectonics 11(4): 766-791.

Moody, J. M., and J. G. Maisey

1993. New Cretaceous marine vertebrate assemblages from north-western Venezuela and their significance. J. Vertebr. Paleontol. 14(1): 1-8.

Norden, C. R.

1961. Comparative osteology of representative salmonid fishes, with particular reference to the grayling (Thymallus 
arcticus) and its phylogeny. Fish. Res. Board Can. J. 18(5): 679-791.

Olney, J. E., G. D. Johnson, and C. C. Baldwin 1993. Phylogeny of lampridiform fishes. Bull. Mar. Sci. 52: 137-169.

Patterson, C.

1975. The braincase of pholidophorid and leptolepid fishes, with a review of the actinopterygian braincase. Philos. Trans. R. Soc. London B Biol. Sci. 269(899): 275-579.

1993. Teleostei. In M. J. Benton (ed.), The fossil record 2: 621-656. London: Chapman and Hall.

Patterson, C., and D. E. Rosen

1977. Review of ichthyodectiform and other Mesozoic teleost fishes and the theory and practice of classifying fossils. Bull. Am. Mus. Nat. Hist. 158(2): 81-172.

Pons, D., P.-Y. Berthou, and D. A. Campos

1990. Quelques observations sur la palynologie de l'Aptien Supérieur et de l'Albien du Bassin d'Araripe (NE du Brésil). Atas 1 Simp. Bacia do Araripe e bacias interiores do Nordeste, Crato: 241-252.

Popoff, M.

1988. Du Gondwana à l'Atlantique sud: les connexions du fossé de las Bénoué avec les bassins du Nord-Est brésilien jusqu'a l'overture du golfe de Guinée au Crétacée inférieur. In J. Sougy and J. Rodgers (eds.), The West African connection. J. Afr. Earth Sci. Spec. Publ. 7(2): 409-431.

Rabinowitz, P. D., and J. LaBrecque

1979. The Mesozoic South Atlantic Ocean and the evolution of its continental margin. J. Geophys. Res. 84: 59736002 .

Renz, O.

1982. The Cretaceous Ammonites of Venezuela. Basel: Birkhauser. 132 pp.

Reyment, R. A., and R. V. Dingle

1987. Palaeogeography of Africa during the Cretaceous period. Palaeogeogr. Palaeoclimatol. Palaeoecol. 59: 93-116.

Roberts, C. D.

1993. Comparative morphology of spined scales and their phylogenetic significance in the Teleostei. Bull. Mar. Sci. 52(1): 29-59.
Rosen, D. E.

1973. Interrelationships of higher euteleostean fishes. In P. H. Greenwood, R. S. Miles, and C. Patterson (eds.), Interrelationships of fishes: 397-513. London: Academic Press.

1985. An essay on euteleostean classification. Am. Mus. Novitates 2827: 57 pp.

Schultze, H.-P., and D. Stöhr

1996. Vinctifer (Pisces, Aspidorhynchidae) aus de Unterkreide (oberes Aptium) von Kolumbien. Neues Jahrb. Geol. Paläontol. Abh. 199(3): 395-415.

Silva Santos, R. da

1983. Araripichthys castilhoi novo genero e especie de acantopterigio da Formacao Santana, Chapada do Araripe, Brasil. VIII Congr. Bras. Paleontol., Rio de Janeiro, 1983, Resumos comm, p. 27.

1985a. Araripichthys castilhoi novo gênero e especie de teleostei da Formação Santana, Chapada do Araripe, Brasil. In D. A. Campos, C. S. Ferreira, I. M. Brito, and C. F. Viana (eds.), Coletânea de Trabalhos Paleontológicos, Série Geologia 27(2): 133-140. Rio de Janeiro: Ministério das Minas e EnergiaD.N.P.M.

1985b. A icitofáuna de Formação Riachuelo, Estado de Sergipe. VIII Congr. Bras. Paleontol., Rio de Janeiro, 1983, Serv. Geol. 27: 141-145.

Silva Santos, R. da, and A. R. de Oliveira

1994. Rhacolepis buccalis Agassiz, 1841 (Pisces, Elopomorpha), no Crétaceo Inferior da Colômbia, AS. An. Acad. Bras. Ciênc. 66(2): 167-171.

Stiassny, M. L. J.

1986. The limits and relationships of the acanthomorph teleosts. J. Zool. Ser. B. 1986: 411-460.

Szatmari, P., J.B.L. Françolin, O. Zanotto, and S. Wolff

1987. Evolução tectônica da margem equatorial Brasileira. Rev. Bras. Geociênc. 17(2): 180-188.

Weeks, L. G.

1953. Environment and mode of origin and facies relationship of carbonate concretions in shales. J. Sediment. Petrol. 23: $162-173$.

1957. Origin of carbonate concretions in shales, Magdalena Valley, Colombia. Bull. Geol. Soc. Am. 66: 95-102. 


\section{APPENDIX 1}

\section{Character List for Selected Teleostean Groups}

Key to abbreviations: PR = Patterson and Rosen (1977); Ar = Arratia, 1996; J = Johnson, 1992; JP = Johnson and Patterson, 1996; O = Olney et al., 1993; $\mathrm{S}=$ Stiassny, 1986; $\mathrm{R}=\mathrm{Rosen}, 1985$. (Note that the authors listed are not necessarily the original authors of the character.)

Taxa: Araripichthys (Ara) Acanthichthys (Ac) Ferrifrons (Fe).

Derived state of character: present (P), absent (A), uncertain (P?; A?), unknown (?), not applicable (-).

\begin{tabular}{|c|c|c|c|}
\hline Character & Ara & $\mathrm{Ac}$ & $\mathrm{Fe}$ \\
\hline \multicolumn{4}{|l|}{ Elopocephala (PR) } \\
\hline Two uroneurals & $\mathbf{P}$ & $\mathrm{P}$ & $?$ \\
\hline \multicolumn{4}{|l|}{ Osteoglossomorphs + clupeocephalans (Ar) } \\
\hline Posterior opening of mandibular canal lateral to angular & A & $?$ & $?$ \\
\hline First dorsal pterygiophore a single structure & $\mathrm{P}$ & $\mathrm{P}$ & $\mathrm{P}$ \\
\hline NPU2 as long as NPU3 & $\mathrm{P}$ & $\mathbf{P}$ & $?$ \\
\hline Not more than seven hypurals & $\mathrm{P}$ & $\mathbf{P}$ & ? \\
\hline Hypural 8 absent (!) & $\mathbf{P}$ & $\mathbf{P}$ & $?$ \\
\hline Cycloid scales with crenulate posterior margin & $\mathbf{P}$ & $P ?$ & $?$ \\
\hline \multicolumn{4}{|l|}{ Elopomorpha } \\
\hline Leptocephalus larva (PR) & $?$ & $?$ & $?$ \\
\hline Angular fused to retroarticular (PR) & A & $\mathrm{P}$ & $?$ \\
\hline Articular partially fused to anguloretroarticular (Ar) & A & $?$ & $?$ \\
\hline Rostral and prenasal ossicles present (PR) & A & A & $?$ \\
\hline PU1+U1 with compound neural arch (PR, Ar) & A & $\mathrm{A}$ & $?$ \\
\hline Broad mesethmoid carrying ethmoid commissure (Ar) & $\mathrm{P}$ ? & $?$ & $?$ \\
\hline Elongate jaws with numerous viliform teeth (Ar) & A & A & A \\
\hline Hypurapophysis(es) present (Ar) & A & A & $?$ \\
\hline Two long separate uroneurals (Ar) & $P ?$ & $\mathrm{P} ?$ & $?$ \\
\hline \multicolumn{4}{|l|}{ Clupeocephala } \\
\hline Angular fused to articular (PR) & A & $\mathrm{P}$ & $?$ \\
\hline Retroarticular excluded from joint with quadrate (PR, Ar) & A & $?$ & $?$ \\
\hline U1 with membranous anterodorsal outgrowth (PR) & A & $\mathrm{P} ?$ & $?$ \\
\hline U1\&2 or "first" ural centrum lacks neural spine (Ar) & $\mathrm{P}$ & $\mathrm{P}$ & $?$ \\
\hline U1\&2 or "first" ural centrum lacks neural arch (Ar) & $\mathrm{P}$ & $\mathrm{P}$ & $?$ \\
\hline NU1 reduced/absent (PR) & $\mathrm{P}$ & $\mathrm{P}$ & $?$ \\
\hline One long uroneural (Ar) & A & A & $?$ \\
\hline Hypural 7 absent (Ar) & A & $\mathrm{P}$ & $?$ \\
\hline Tail flexion begins at PU1 or U1 $\left(\mathrm{Ar}^{a}\right)$ & $\mathrm{P}$ & $\mathrm{P}$ & $?$ \\
\hline Fusion of toothplates + pbr $1-3$ and cbr5 (PR) $\left(\mathrm{Ar}^{b}\right)$ & $?$ & $?$ & $?$ \\
\hline Fewer than four pharyngobranchials (Ar) & ? & $?$ & $?$ \\
\hline \multicolumn{4}{|l|}{ Euteleostei } \\
\hline Adipose fin (PR) & $\mathrm{A}$ ? & A? & $?$ \\
\hline Nuptial tubercles (PR) & $?$ & $?$ & $?$ \\
\hline Stegural not meeting opposite member at midline (PR) & A? & A? & $?$ \\
\hline "Pattern 2 supraneurals" (JP) & $?$ & $?$ & $?$ \\
\hline Caudal median cartilages (JP) & $?$ & $?$ & $?$ \\
\hline \multicolumn{4}{|l|}{ Neoteleostei $(J)$} \\
\hline exo and boc exposed posteriorly, with inverted Y suture & $\mathrm{P} ?$ & $?$ & $?$ \\
\hline "Type 4" tooth attachment & A & A & $?$ \\
\hline Retractor dorsalis muscle & $?$ & $?$ & $?$ \\
\hline 3rd internal levator inserted on 5 th pharyngeal toothplate ${ }^{c}$ & $?$ & $?$ & $?$ \\
\hline \multicolumn{4}{|l|}{ Eurypterygii } \\
\hline Toothplate fused to 3rd epibranchial (J) & $?$ & $?$ & $?$ \\
\hline Interoperculohyoid ligament present $(\mathbf{J})$ & $?$ & $?$ & ? \\
\hline Ventral half of medial pelvic ray and medial radial fused $(\mathrm{J})$ & - & $?$ & $?$ \\
\hline \multicolumn{4}{|l|}{ Ctenosquamata } \\
\hline 3rd internal levator +5 th upper pharyngeal toothplate lost $(\mathrm{J})$ & $?$ & ? & $?$ \\
\hline
\end{tabular}


APPENDIX 1

Continued

\begin{tabular}{|c|c|c|c|}
\hline Character & Ara & Ac & $\mathrm{Fe}$ \\
\hline \multicolumn{4}{|l|}{ Acanthomorpha } \\
\hline Dorsal and anal median fin spines (JP) & A & P? & P? \\
\hline Rostral cartilage present $(\mathrm{JP})$ & $?$ & $?$ & $?$ \\
\hline Lateral ethmoids close to or fused with vomer $(\mathrm{S})$ & A? & A? & ? \\
\hline Median caudal cartilages absent (JP) & $?$ & $?$ & $?$ \\
\hline Separate anterior and medial infracarinales muscles $(S)$ & ? & $?$ & $?$ \\
\hline Post-temporal dorsal limb bound to epioccipital (S) & $?$ & ? & $?$ \\
\hline Medial pelvic process ossified distally (JP) & - & $\mathrm{P}$ & $?$ \\
\hline First centrum with facets for exoccipital (R) & $\mathrm{P}$ & $\mathrm{P}$ & ? \\
\hline \multicolumn{4}{|l|}{ Euacanthomorpha (JP) } \\
\hline Ist epineural displaced ventrally into horizontal septum & A & ? & ? \\
\hline Posterior pelvic process ossified distally & - & ? & ? \\
\hline Spina occipitalis & A & A & ? \\
\hline Origin of anterior epineurals displaced ventrally & A & $?$ & ? \\
\hline \multicolumn{4}{|l|}{ Holacanthopterygii (JP) } \\
\hline epipleurals absent & ? & ? & ? \\
\hline epicentral ligaments absent anteriorly & ? & ? & ? \\
\hline distal parts of anterior epineurals in horizontal septum & ? & $?$ & ? \\
\hline \multicolumn{4}{|l|}{ Lampridiformes $(\mathrm{O})$} \\
\hline ant. palatine process (and palatomaxillary ligament) absent & A & A & A \\
\hline mesethmoid posterior to lateral ethmoids & A & A & A \\
\hline frontal vault for premaxillary ascending process & A & A & A \\
\hline first dorsal pterygiophore anterior to first neural spine & $\mathrm{A}$ & A & A \\
\hline
\end{tabular}

aCrown teleost character according to PR.

bCharacter coding reversed in Arratia, 1996.

"Absence of this levator muscle and toothplate is "unique to and unreversed within the Ctenosquamata" $(\mathbf{J}: 21)$. 
Recent issues of the Novitates may be purchased from the Museum. Lists of back issues of the Novitates and Bulletin published during the last five years are available at World Wide Web site http://nimidi.amnh.org. Or address mail orders to: American Museum of Natural History Library, Central Park West at 79th St., New York, NY 10024. TEL: (212) 769-5545. FAX: (212) 7695009. E-MAIL: scipubs@amnh.org

(2) This paper meets the requirements of ANSI/NISO Z39.48-1992 (Permanence of Paper). 